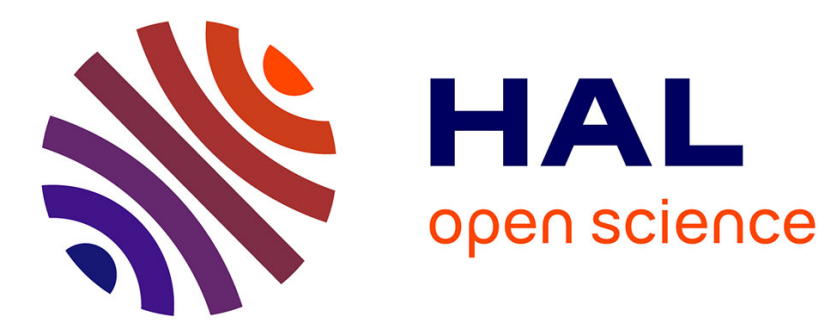

\title{
Genesis of corrugated fault surfaces by strain localization recorded at oceanic detachments
}

Ross Parnell-Turner, Javier Escartin, Jean-Arthur Olive, Deborah Smith, Sven E Petersen

\section{- To cite this version:}

Ross Parnell-Turner, Javier Escartin, Jean-Arthur Olive, Deborah Smith, Sven E Petersen. Genesis of corrugated fault surfaces by strain localization recorded at oceanic detachments. Earth and Planetary Science Letters, 2018, 498, pp.116-128. 10.1016/j.epsl.2018.06.034 hal-02330321

\section{HAL Id: hal-02330321 \\ https://hal.science/hal-02330321}

Submitted on 19 Oct 2021

HAL is a multi-disciplinary open access archive for the deposit and dissemination of scientific research documents, whether they are published or not. The documents may come from teaching and research institutions in France or abroad, or from public or private research centers.
L'archive ouverte pluridisciplinaire HAL, est destinée au dépôt et à la diffusion de documents scientifiques de niveau recherche, publiés ou non, émanant des établissements d'enseignement et de recherche français ou étrangers, des laboratoires publics ou privés. 
1 Genesis of corrugated fault surfaces by strain localization recorded at oceanic detachments

4 Ross Parnell-Turner ${ }^{1}$, Javier Escartín ${ }^{2}$, Jean-Arthur Olive ${ }^{3}$, Deborah K. Smith ${ }^{4}$, and

5 Sven Petersen 5

$6{ }^{1}$ Department of Geology and Geophysics, Woods Hole Oceanographic Institution, Woods

$7 \quad$ Hole, Massachusetts 02543, USA

$8{ }^{2}$ CNRS / Institut de Physique du Globe de Paris, 1 rue Jussieu, 75005, Paris, France.

$9{ }^{3}$ Laboratoire de Géologie, Ecole Normale Supérieure / CNRS UMR 8538, PSL Research

10 University, 24 rue Lhomond, 75005, Paris, France.

$11{ }^{4}$ National Science Foundation, 2415 Eisenhower Ave., Alexandria, VA, 22314, USA.

$12{ }^{5}$ GEOMAR / Helmholtz Centre for Ocean Research, Wischhofstrasse 1-3, 24148, Kiel,

13 Germany.

15 Keywords

16 Oceanic detachment faulting; mid-ocean ridge; corrugations

18 Abstract

19 Seafloor spreading at slow and ultraslow rates is often taken up by extension on large-

20 offset faults called detachments, which exhume lower crustal and mantle rocks, and in

21 some cases make up domed oceanic core complexes. The exposed footwall may reveal a

22 characteristic pattern of spreading-parallel corrugations, the largest of which are clearly

23 visible in multibeam bathymetric data, and whose nature and origin have been the subject

24 of controversy. In order to tackle this debate, we use available near-bottom bathymetric

25 surveys recently acquired with autonomous deep-sea vehicles over five corrugated

26 detachments along the Mid-Atlantic Ridge. With a spatial resolution of $2 \mathrm{~m}$, these data

27 allow us to compare the geometry of corrugations on oceanic detachments that are

28 characterized by differing fault zone lithologies, and accommodate varying amounts of

29 slip. The fault surfaces host corrugations with wavelengths of 10-250 m, while individual

30 corrugations are finite in length, typically 100-500 m. Power spectra of profiles

31 calculated across the corrugated fault surfaces reveal a common level of roughness, and 
32 indicate that the fault surfaces are not fractal. Since systematic variation in roughness

33 with fault offset is not evident, we propose that portions of the exposed footwalls

34 analyzed here record constant brittle strain. We assess three competing hypotheses for

35 corrugation formation and find that the continuous casting and varying depth to brittle-

36 ductile transition models cannot explain the observed corrugation geometry nor available

37 geological observations. We suggest a model involving brittle strain localization on a

38 network of linked fractures within a zone of finite thickness is a better explanation for the

39 observations. This model explains corrugations on oceanic detachment faults exposed at

40 the seafloor and on normal faults in the continents, and is consistent with recently imaged

41 corrugations on a subduction zone megathrust. Hence fracture linkage and coalescence

42 may give rise to corrugated fault zones, regardless of earlier deformation history and

43 tectonic setting.

44

45 1. Introduction

46

47 Large-offset normal faults, known as detachments, are now understood to play a

48 significant role in accommodating plate separation at slow- and ultraslow-spreading mid-

49 ocean ridges (e.g. Escartín and Canales, 2011). This style of crustal accretion accounts

50 for seafloor formation in large parts of the Atlantic, Indian and Arctic Oceans; for

51 example, up to $50 \%$ of lithosphere accreted along the Mid-Atlantic Ridge (MAR)

52 between $12.5^{\circ}$ and $35^{\circ} \mathrm{N}$ is thought to be formed in the presence of detachment faults

53 (Escartín et al., 2008). Seafloor spreading under these conditions leads to the exhumation

54 of lower crustal and mantle rocks on the seafloor forming domes that can be tens of

55 kilometers in width called oceanic core complexes (OCCs; e.g. Karson and Dick, 1983).

56 These domes are exposed detachment fault footwalls, which preserve a history of ductile

57 and brittle deformation, in a setting where magmatism and slip play important roles (e.g.

58 Karson et al., 2006; Schroeder and John, 2004). The upper surface of OCCS are often

59 characterized by spreading-parallel corrugations, which have been compared to those

60 found on terrestrial normal faults (e.g. Whitney et al., 2013), and more recently, to those

61 imaged on a subduction zone megathrust (Edwards et al., 2018).

62 Early seafloor mapping efforts revealed oceanic detachment corrugations with 63 wavelengths of a few kilometers to hundreds of meters (Figure 1a; e.g. Tucholke et al., 64 1998), however observations were limited by the $\sim 100 \mathrm{~m}$ spatial resolution of ship- 
65 mounted multibeam systems at the time. Images acquired using deep-towed sonars also 66 revealed lineations at smaller spatial scales, superimposed on these larger-scale 67 bathymetric corrugations (Cann et al., 1997; MacLeod et al., 2009; Searle et al., 2003).

68 Recent developments in near-bottom mapping using autonomous underwater vehicles 69 (AUVs) at $\sim 1-2 \mathrm{~m}$ resolution have revealed much smaller wavelength $(\sim 10 \mathrm{~m})$ 70 oscillations in fault topography, in addition to previously known bathymetric 71 corrugations (Figure 1b). Recent submersible dives have revealed meter-scale 72 corrugations and striations at outcrop scale (Figure 1c; Escartín et al., 2017; Bonnemains 73 et al., 2017), and spreading-parallel striations on the $\mathrm{cm}$-scale in hand specimen (Figure 74 1d; Bonnemains et al., 2017). While it is now well-established that corrugations occur on 75 a wide range of scales, the mechanisms of corrugation development remain controversial, 76 due to a lack of comparable quantitative observations across multiple sites.

The largest, kilometer-scale undulations have been compared to networks of cuspate fault scarps (John, 1987), and to shortening features seen on the footwalls of 79 terrestrial detachments undergoing compression (Fletcher and Bartley, 1994; Tucholke et 80 al., 1998). Karson (1999) suggested that undulations on the Kane massif on the MAR are 81 ridge-perpendicular faulted blocks accommodating extension, although more recent 82 observations at higher resolution have shown this to be unlikely (e.g. MacLeod et al., 83 2002). It has also been suggested that corrugations on the scale of hundreds of meters 84 could arise due to depth variations in the brittle-ductile transition on which the fault roots 85 (Tucholke et al., 2008). Alternatively, corrugations could arise due to the molding of a 86 plastic or partially molten footwall in contact with a strong, brittle hanging wall, in a 87 process termed continuous casting (Spencer, 1999). More recently, corrugations on 88 detachment fault exposures at $13^{\circ} \mathrm{N}$ on the Mid-Atlantic Ridge have been explored by a 89 combination of AUV surveys, remotely operated vehicle (ROV) observations and 90 sampling (Escartín et al., 2017). These near-bottom observations have led to a suggestion 91 that strain localization within an anastomosing three-dimensional network of fault 92 segments results in corrugation formation (Escartín et al., 2017).

93 In order to evaluate these competing hypotheses for the origin of corrugations, we 94 use near-bottom bathymetric data acquired in recent years by AUVs at five OCCs on the 95 MAR to quantify the fine-scale structure and morphology of exposed fault planes. Our 96 objective is to characterize the geometry of meter- to kilometer-scale corrugations, and 97 compare these across detachments of differing age and lithology in order to test 
hypotheses regarding their origins. We then use these observations of corrugation

99 geometry to constrain simple thermal and mechanical arguments for corrugation

100 formation that are implied by the different hypotheses. Finally, we use spectral analyses

101 of the fault surfaces to examine variations in fault roughness between the five study

102 locations. Fault roughness plays a key role in fault and earthquake mechanics, and here

103 we explore the possible implications for corrugation formation.

\section{2. Study Sites and Data Acquisition}

106 We use near-bottom multibeam bathymetric data acquired using AUVs at five locations 107 on the MAR to study fine-scale corrugations (Figures 2 and 3): one at the Trans-Atlantic 108 Geotraverse (TAG) segment; two at the $16.5^{\circ} \mathrm{N}$ segment $\left(16^{\circ} 36^{\prime} \mathrm{N}\right.$ and South Core 109 Complex; SCC) and two at the $13^{\circ} \mathrm{N}$ segment $\left(13^{\circ} 20^{\prime} \mathrm{N}\right.$ and $\left.13^{\circ} 30^{`} \mathrm{~N}\right)$. Well-developed 110 OCCs, with varying lengths of exposed fault surface (a proxy for displacement on the 111 fault), are found at these locations, providing an opportunity to compare the morphology 112 of fine-scale corrugations at high resolution $(\sim 1 \mathrm{~m})$.

\section{$114 \quad$ 2.1 TAG Detachment Fault}

116 A $30 \mathrm{~km}$-wide, domed OCC is located on the eastern flank of the MAR at the TAG 117 segment near $26.17^{\circ} \mathrm{N}$, with full spreading rate of $21 \mathrm{~km} \mathrm{Ma}^{-1}$ (Figure 2b; Tivey et al., 118 2003). This well-studied segment hosts numerous inactive hydrothermal mounds and a 119 large active hydrothermal vent field on the detachment hanging wall (e.g. Rona et al., 120 1993). Age dating suggests that intermittant hydrothermal activity within this segment 121 started as early as 140 ka ago (Lalou et al., 1995), while intense microearthquake activity 122 indicates that the fault is active today (deMartin et al., 2007). Human-occupied 123 submersible dives by ALVIN and MIR found significant mass wasting on the upper 124 slopes of the footwall (chaotic terrain, defined below), however in-situ observations and 125 sampling of the exposed corrugated footwall mapped during the AUV survey presented 126 here are lacking, meaning that the footwall lithology remains uncertain (Karson and 127 Rona, 1990; Zonenshain et al., 1989).

128 Near-bottom bathymetric data were acquired over a small, corrugated portion of 129 the TAG detachment during AUV Abyss dive 235 as part of RV Meteor Cruise M127 in 130 June 2016 (GEOMAR, Germany). The corrugations were undetected by shipboard 
131 multibeam sonars until being mapped by AUV. Abyss surveyed at $80 \mathrm{~m}$ above the

132 seafloor at an average velocity of $\sim 3 \mathrm{kt}\left(1.54 \mathrm{~m} \mathrm{~s}^{-1}\right)$, carrying a RESON 7125 multibeam

133 sonar operating at $200 \mathrm{kHz}$. Navigation was achieved using two long baseline

134 transponders deployed on the seabed, and the data were processed using MB-System

135 software (Caress and Chayes, 1996) to produce a $\sim 2 \mathrm{~m}$ horizontal resolution grid (Figure

$1363 a)$.

137

\section{$138 \quad 2.2$ South Core Complex and $\mathrm{OCC}^{16^{\circ}} 36^{\prime} \mathrm{N}$}

140 The $16.5^{\circ} \mathrm{N}$ segment of the MAR, located $\sim 100 \mathrm{~km}$ north of the Fifteen-Twenty Fracture

141 Zone, is characterized by numerous detachment faults and OCC domes distributed on

142 both sides of the axis, which is spreading at a rate of $21 \mathrm{~km} \mathrm{Ma}^{-1}$ (Parnell-Turner et al.,

143 2016; Smith et al., 2014). Here, we use near-bottom bathymetric data acquired over two

144 corrugated surfaces in the $16.5^{\circ} \mathrm{N}$ area. The first is a $\sim 10 \mathrm{~km}$-wide domed, corrugated

145 detachment fault called South Core Complex (SCC) located west of the axis, clearly

146 identified from shipboard bathymetric data (Figure 3c). Rock samples dredged from this

147 fault surface included gabbro and serpentinized peridotite (Smith et al., 2014). Second,

148 we examine a $\sim 5 \mathrm{~km}$-wide corrugated surface located $20 \mathrm{~km}$ north of SCC at $16^{\circ} 36^{\prime} \mathrm{N}$

149 (Figure 3b), where dredges containing diabase, diabase breccia and peridotite were

150 recovered (Smith et al., 2014). In common with TAG, these corrugations were not

151 detected by shipboard multibeam sonars, while thin sediment cover shows that the fault at

$15216^{\circ} 36^{\prime} \mathrm{N}$ is likely to be slipping today (Parnell-Turner et al., 2014).

153 Near-bottom bathymetric surveys over SCC (dives 176, 177, and 180) and OCC

$15416^{\circ} 36^{\prime} \mathrm{N}$ (dive 181) were carried out using AUV Sentry (Woods Hole Oceanographic 155 Institution, USA) in May 2013 during RV Knorr Cruise KN210-05 (Smith et al., 2014).

156 Sentry flew at $\sim 65 \mathrm{~m}$ above the seafloor at a velocity of $\sim 1.5 \mathrm{kt}\left(0.77 \mathrm{~m} \mathrm{~s}^{-1}\right)$ carrying a

157 RESON 7125 multibeam sonar operating at $400 \mathrm{kHz}$. Navigation was achieved using an

158 ultra-short baseline system, and the data were processed using MB-System software to 159 produce a $\sim 2 \mathrm{~m}$ horizontal resolution grid.

\section{$161 \quad 2.31^{\circ} 30^{\prime} \mathrm{N}$ and $13^{\circ} 20^{\prime} \mathrm{N}$ OCCs}

162 A series of well-developed detachment faults and associated OCCs were first identified 163 between $12^{\circ} 55^{\prime}$ and $13^{\circ} 45^{\prime} \mathrm{N}$ along the MAR using shipboard bathymetry surveys and 
164 seismicity detected by autonomous hydrophones (Smith et al., 2008). Near-bottom 165 imaging revealed a $6 \mathrm{~km}$-wide corrugated dome at $13^{\circ} 20^{\prime} \mathrm{N}$, which is thought to represent $166 \sim 0.4$ Ma of slip (Figure 3e; MacLeod et al., 2009; Mallows and Searle, 2012). High rates 167 of microearthquake activity are evident today (Parnell-Turner et al., 2017), while AUV168 based water column studies and remotely-operated vehicle (ROV) dives revealed the 169 active high-temperature $\left(\sim 365^{\circ} \mathrm{C}\right)$ Irinovskoe vent field, near the crest of the dome 170 (Escartín et al., 2017). A second OCC, $20 \mathrm{~km}$ to the north at $13^{\circ} 30^{\prime} \mathrm{N}$, has similar 171 corrugated morphology, however it is degraded by normal faulting, fissuring, mass172 wasting, and hydrothermal deposition (see Escartín et al., 2017). These processes have 173 probably partially disrupted and modified the corrugations (Figure 3d). In-situ sampling 174 using a remotely-operated vehicle (ROV) revealed contrasting lithologies at these two 175 detachment zones: the $13^{\circ} 20^{\prime} \mathrm{N}$ corrugated surface is primarily basalt breccia, while 176 gabbro and peridotite are more common at $13^{\circ} 30^{\prime} \mathrm{N}$ OCC (Escartín et al., 2017). Both 177 the $13^{\circ} 20^{\prime} \mathrm{N}$ and $13^{\circ} 30^{\prime} \mathrm{N}$ OCCs host several inactive and active hydrothermal vent fields 178 (Cherkashov et al., 2010). Near-bottom bathymetric data (doi:10.17882/48335) were 179 acquired during 9 dives of AUV Abyss as part of the ODEMAR Cruise 180 (doi:10.17600/13030070) onboard N/O Pourquoi Pas? in December 2013 (Escartín et al., 181 2017). Abyss flew at $\sim 70 \mathrm{~m}$ above the seafloor carrying a RESON 7125 multibeam sonar 182 operating at $200 \mathrm{kHz}$; resulting data were processed using MB-System and gridded at $\sim 2$ 183 m horizontal spacing.

\section{3. Corrugation analysis}

188 The near-bottom AUV bathymetric data described above reveal the detailed morphology 189 of corrugations which is unresolved by shipboard multibeam data (Figure 1). Four 190 distinct morphological terrains (defined in terms of bathymetric relief) can be identified 191 at these OCCs, the complete sequence of which can be seen at the $13^{\circ} 20^{\prime} \mathrm{N}$ OCC (Figure 192 5e; for details see Escartín et al., 2017). First, nearest to the axis and occupying the rift 193 valley floor is the volcanic terrain, which consists of hummocky seafloor, basalt flows 194 and cones. Second, between the volcanic terrain and the hanging-wall cutoff (sometimes 195 called the termination), is the apron, which is a narrow band (a few hundreds of meters to $196 \sim 1 \mathrm{~km}$ wide) of relatively smooth seafloor that skirts the curved hanging-wall cutoff and 
197 that the detachment drags and uplifts with respect to adjacent volcanic terrain. The 198 hanging-wall cutoff itself often consists of a well-defined depression (described as a 199 moat) that can be traced over a few kilometers. This moat is tens to $\sim 250$ m wide, $\sim 10-15$ $200 \mathrm{~m}$ deep and is interpreted to mark the transition from hanging wall to footwall (yellow 201 arrows in Figure 4; Escartín et al, 2017). An apron bordering the hanging-wall cutoff is 202 also observed at the TAG and $16^{\circ} \mathrm{N}$ segment OCCs. Third is the fault surface itself, that 203 emerges adjacent to the hanging-wall cutoff, and is characterized by spreading-parallel 204 corrugations. Irregularly distributed rubble ridges are sometimes observed in depressions 205 between the km-scale corrugations ( $16^{\circ} 36^{\prime} \mathrm{N}$ and $13^{\circ} 20^{\prime} \mathrm{N}$ OCCs; Figures 4 and 5 ). These 206 ridges, typically $\sim 100-150 \mathrm{~m}$ long, $2-4 \mathrm{~m}$ in relief and oriented parallel to the hanging207 wall cutoff, may represent apron material which has episodically slumped onto the 208 detachment footwall (Escartín et al., 2017). Fourth, the chaotic terrain is located between 209 the distal edge of the corrugated surface and the detachment fault breakaway, and 210 consists of a morphologically complex area likely resulting from mass-wasting of the 211 footwall cut off scarp at the initiation of the detachment fault (Escartín et al., 2017).

212 We identify and digitize individual corrugations on the exposed footwall of each 213 OCC using bathymetric relief maps, calculated by applying a $200 \mathrm{~m}$ wide Gaussian filter 214 in the slip-normal direction, which removes the overall domal morphology and reveals 215 corrugations (Supplementary Figure 1). Individual corrugations, visually interpreted in 216 map view, are shown in Figure 5.

217 Corrugations are evident on the exposed fault surfaces, and are also often visible 218 axis-ward of the hanging-wall cutoff, indicating that the hanging wall apron is thin 219 enough to reflect the prominent surface morphology of the underlying detachment fault 220 (Figure 5). The appearance of corrugations on the apron also suggests that the apron is 221 relatively thin, draping over the fault surface prior to its emergence at the seafloor, and 222 revealing the underlying corrugations. Corrugations show a consistent alignment at each 223 study site, typically within $\pm 5^{\circ}$ of the mean plate spreading direction (Supplementary 224 Figure 2). This consistency implies that the process that governs corrugation azimuth is 225 relatively constant and linked to the extension along the fault, and thus corrugation 226 azimuth is a useful kinematic indicator. Corrugations often have well-defined end-points 227 (Figure 4 and Supplementary Figure 1), indicating that they are discrete features with 228 limited spatial (and thus probably temporal) extent in the displacement-parallel direction. 
232 The bathymetric data presented here allow us to assess the meter-scale geometry of 233 corrugations at the five study sites. We quantify corrugation geometry in terms of spacing 234 between corrugations, length along the spreading direction, width perpendicular to the 235 spreading direction, and aspect ratio defined as length/width (Figure 6). The spreading236 perpendicular distance between adjacent corrugations picked from relief maps 237 (Supplementary Figure 1) is expressed as a probability density function, calculated using 238 a kernel density estimation method (Figure 6a; Sheather and Jones, 1991). Corrugation 239 length (measured parallel to slip) is plotted in Figure 6b, width perpendicular to slip is 240 plotted in Figure 6d, and these two measurements are used to estimate aspect ratio, which 241 is plotted in Figure 6d.

242 Corrugations are typically spaced 50 to $250 \mathrm{~m}$ apart, with a slight positive skew

243 (i.e., higher number of corrugations spaced closer together) at all five sites. This spacing 244 agrees well with that of lineations identified using near-bottom towed sidescan images at 245 Atlantis Massif and $13^{\circ} \mathrm{N}$ on the MAR (Cann et al., 1997; MacLeod et al., 2009), and at 246 the FUJI dome on the Southwest Indian Ridge (Searle et al., 2003).

247 Corrugations at SCC are most commonly spaced at $\sim 100 \mathrm{~m}$. This is a slightly 248 larger spacing than that observed at the other four sites, which are commonly spaced at $249 \sim 60 \mathrm{~m}$ (Figure 6a). Corrugations appear to be discrete in length, i.e. do not extend across 250 the entire exposed fault surface. Lengths vary between tens of meters to $\sim 1500 \mathrm{~m}$, and are 251 mostly 100-500 m long across all sites (Figure 6b), although these length estimates 252 probably represent lower bounds. Mass-wasting products may cover up corrugation ends 253 at the chaotic terrain boundary (Figure 5), while some corrugations may only be partially 254 exposed from beneath the hanging wall apron at the axial-side of the fault surface. 255 Corrugations range in width between 20 and $100 \mathrm{~m}$, with a positive skew at all sites, 256 which reflects that most corrugations are 20-50 m wide (Figure 6c). These measurements 257 at the fault surface reveal that the aspect ratio of corrugations is typically $\sim 10: 1$, but can 258 be as high as $\sim 50: 1$ in a few cases (Figure $6 \mathrm{~d}$ ). Given that the full length of some 259 corrugations may be partly obscured (by mass wasting or hydrothermal deposits, for 260 example), these estimates of aspect ratio also represent lower bounds.

\subsection{Power spectral analysis}


264 A useful measure of corrugation geometry, and of fault roughness, is power spectral 265 density, where higher spectral density implies increased roughness for a given 266 wavelength (Power et al., 1988; Power and Tullis, 1991). We extracted bathymetric 267 profiles spaced $50 \mathrm{~m}$ apart and oriented parallel and perpendicular to slip from patches of 268 exposed fault surface at each study location (Figure 7). We then calculated power spectral 269 density curves for individual profiles using Thomson's multitaper method (Thomson, 270 1982), and summed the spectra together to give single spectra for each direction at each 271 site (Figure 8). At wavelengths below $\sim 10 \mathrm{~m}$, spectra are contaminated by acquisition 272 artifacts. These artifacts arise from vehicle attitude noise (heading, pitch and roll), from

273 navigation errors generated as adjacent swaths are stitched together, and from gridding 274 artifacts when overlapping swaths are merged. Variations in these errors occur both 275 within and between surveys, and cannot be completely removed from the data. At 276 wavelengths of 10 to $250 \mathrm{~m}$, the power spectral density for each of the four corrugated 277 surfaces is similar, reflecting a common level of roughness. The power spectral density 278 function $G(f)$ for the special case of a profile across a surface obeying a fractal scaling 279 law is

$$
G(f)=C f^{-\beta}
$$

281

282 where $f$ is the spatial frequency, $C$ is a constant, and $\beta$ is the slope of the power spectrum 283 (Brown, 1987), and describes how the surface roughness varies with scale. If the power284 law relationship between length scale and roughness is well-fitted over several orders of 285 magnitude, then the fault surface is fractal (e.g. Malamud and Turcotte, 1999); the special 286 case of a well-fitted surface with $\beta=3$, is said to be self-similar (e.g. Brown, 1987; 287 Candela and Renard, 2012). If a surface is self-similar, a small portion of the surface, 288 when magnified isotropically, will appear statistically identical to the entire surface. If a 289 surface is self-affine, a magnified portion of the surface will only appear statistically 290 identical to the entire surface if different magnifications are used for the directions 291 parallel and perpendicular to the surface (e.g. Power and Tullis, 1991). Although slip292 parallel spectra from SCC, $13^{\circ} 30^{\prime} \mathrm{N}$ and $13^{\circ} 20$ are well-fitted with $\beta=3$ at wavelengths 293 of 10-100 m, the power law does not fit over several orders of magnitude at any of the 294 study sites, suggesting that fault surface roughness is not fractal (Figure 8). 
295 Changes in fault surface roughness with increasing slip in terrestrial settings have been 296 interpreted to imply that the nucleation, growth, and termination of earthquakes on well297 established faults are different to that on new ones (e.g. Sagy et al., 2007). Here, we apply

298 the roughness analysis to investigate whether the rupture process varies as a function of

299 slip on oceanic detachment faults. We restrict our analysis to the $13^{\circ} 20^{\prime} \mathrm{N}$ OCC, which 300 has the largest exposed fault surface area. We calculated power spectra for profiles in 301 three adjacent patches of fault surface, which have experienced 1.3, 2.6 and $3.9 \mathrm{~km}$ of 302 slip, respectively, since the fault surface emerged on the seafloor (see boxes 1, 2 and 3 in 303 Figure 9a inset). A comparison of spectra from these three patches shows that they all 304 have a similar level of fault roughness (Figure 9a), implying no variation in fault rupture 305 processes as a function of slip. At a larger scale, slip on the five oceanic detachment fault 306 surfaces analyzed here ranges from $\sim 5 \mathrm{~km}$ at TAG to $\sim 8 \mathrm{~km}$ at $13^{\circ} 20^{\prime} \mathrm{N}$, however no 307 significant differences in slip-parallel fault roughness are apparent (Figure 8). Hence, 308 both within a single detachment surface, and between faults with different slip histories, 309 there does not appear to be variation in fault roughness with slip. We also calculated 310 roughness for profiles from a series of fault patches oriented perpendicular to slip at $3111^{\circ} 20^{\prime} \mathrm{N}$ (see boxes 4, 5 and 6 in Figure 9b inset). We also find no significant variation in 312 roughness between these patches, implying that, at least for the exposed portion of the 313 fault, the rupture process is fairly uniform along strike (i.e. parallel to the spreading axis).

314 These results imply that the process of corrugation nucleation and development is 315 relatively stable throughout the duration of slip on oceanic detachment faults.

\section{4. Corrugated fault formation}

318 The geometric analysis of corrugations based on near-bottom data presented here 319 provides an opportunity to address the ongoing debate about the origin of detachment 320 fault corrugations. Here we compare and evaluate three competing hypotheses for 321 corrugation development.

\section{$323 \quad 4.1$ Continuous casting}

325 In the continuous casting hypothesis, footwall rocks below the detachment fault are 326 suggested to be much weaker than those above the fault, and are molded to conform to 327 the irregular underside of the upper plate during normal fault movement that eventually 
328 led to exhumation of the corrugations (Spencer, 1999). Hence a corrugated pattern is 329 thought to be imprinted onto the upper surface of the more ductile footwall material and

330 to be preserved as the fault continues to slip. Three-dimensional observations of exposed 331 oceanic detachment fault surfaces have shown that corrugations persist beneath the 332 exposed fault surface, and occur in repeated layers within a zone that may be hundreds of 333 meters thick (Bonnemains et al., 2017; Escartín et al., 2017). These findings show that

334 the process of corrugation formation cannot be restricted to the interface between hanging 335 wall and footwall, and must occur over a finite thickness in three dimensions. It is 336 therefore unlikely to be explained by continuous casting, which would only generate 337 corrugations on a single, two-dimensional planar surface. The observed finite corrugation 338 length, with well-defined ends (e.g. Figure 4), is also not predicted by the continuous 339 casting hypothesis, unless the shape of the brittle layer changed over time. The contrast in 340 ductility between hanging wall and footwall would be required to abruptly dissipate and 341 re-appear over very short timescales (thousands of years) in order to form corrugations 342 that are a few hundreds of meters long, requiring an additional mechanism that seems 343 physically improbable.

\subsection{Uneven brittle-ductile transition depth}

347 Tucholke et al., (2008), suggested that episodic, spatially variable magmatism may 348 explain corrugations spaced hundreds of meters apart, in a modified version of the 349 continuous casting hypothesis. Since intrusion of magma along the spreading center is 350 thought to be discontinuous, Tucholke et al., (2008) envision an uneven brittle-plastic 351 transition that would lead to depth-dependent fault initiation and thus the development of 352 corrugations. In their model, the relatively cool hanging-wall would continue to control 353 the shape of the exhuming footwall, with or without further magmatic injection, in a 354 similar fashion to the continuous casting mechanism. In this hypothesis, the wavelength 355 (i.e. spacing) of corrugations must depend upon the length scale of slip-perpendicular (i.e. 356 spreading axis-parallel) rheological heterogeneities within the hanging wall. Such 357 variations in rheology could either be due to variations in melt supply leading to thermal 358 anomalies (Tucholke et al., 2008), or due to variations in the depth extent of 359 serpentinization by seawater. Corrugations are commonly found on oceanic detachment 360 fault surfaces, however the extent of serpentinization varies between sites. For example, 
361 at the corrugated central dome of Atlantis Massif, drilling at site U1309 revealed that 362 intense serpentinization in the upper $\sim 100 \mathrm{~m}$ (Blackman et al., 2011), however samples 363 from the corrugated surface at the $13^{\circ} 20 \mathrm{~N}$ OCC are primarily quartz-cemented basaltic 364 breccias (Bonnemains et al., 2017). Therefore, serpentinization alone is unlikely to cause 365 the required rheological contrast, as it is not common to all detachments studied here. If 366 this rheological contrast were caused by temperature anomalies within the hanging wall, 367 the thermal contrast would need to be sustained for sufficient time for corrugations to 368 form. A typical corrugation observed in AUV data here is 200-500 $\mathrm{m}$ in length (Figure 369 6a), and assuming a half spreading rate of $\sim 10 \mathrm{~km} \mathrm{Ma}^{-1}$, the thermal contrast would need 370 to be sustained for $\tau_{C}=0.2-0.5 \mathrm{Ma}$. Unless it is maintained by a steady, irregular pattern 371 of upward heat advection along the axis, a thermal anomaly of wavelength $\lambda$ at the 372 brittle-ductile transition will diffuse over a characteristic time scale $\tau=\lambda^{2} / \kappa$, where $\kappa$ 373 denotes the thermal diffusivity of the oceanic lithosphere $\left(\sim 3 \times 10^{-6} \mathrm{~m}^{2} \mathrm{~s}^{-1}\right.$; Turcotte and 374 Schubert, 2002). Thus, only thermal anomalies of wavelengths greater than $\lambda_{C}=\sqrt{\kappa \tau_{C}}=$ 375 4-7 km can be sustained over sufficiently long time to mold a typical corrugation.

377 Since corrugations are typically spaced $\sim 100 \mathrm{~m}$ apart or less (Figure $6 \mathrm{a}$ ), it is unlikely 378 that the necessary thermal contrast within the hanging wall could be sustained for a 379 sufficient amount of time. A thermal anomaly with $\lambda=100 \mathrm{~m}$, which would explain the 380 typical spacing of corrugations observed in near-bottom multibeam data here and in 381 shipboard multibeam data elsewhere, would dissipate within $\sim 100$ years. At a nominal 382 half spreading rate of $10 \mathrm{~km} \mathrm{Ma}^{-1}$, such a thermal anomaly could only generate a 383 corrugation that is $\sim 1 \mathrm{~m}$ long, which is two orders of magnitude smaller than observed 384 corrugation lengths (Figure 6b).

Alternatively, a thermal anomaly could be maintained by steady-state advection of heat into the same patch of the ridge axis during the time required to form a corrugation, thus generating a depth-varying brittle-ductile transition. This scenario is implausible for three reasons: First, there is no geological observation consistent with this type of behavior; 390 second, there is no straightforward mechanism for maintaining such thermal anomalies 391 over the necessary period of $0.2-0.5 \mathrm{Ma}$; third there is no evidence for thermal anomalies 392 with such regular, close spacing at the ridge axis, as would be required. These simple 393 scaling arguments, combined with the detailed observations and sampling of corrugated 
394 surfaces and samples from the fault zone, demonstrate that variations in the brittle-ductile 395 transition cannot explain corrugations on the scales observed at oceanic detachment 396 faults.

\subsection{Strain localization along anastomosing faults}

400 An alternative explanation for corrugation genesis on oceanic detachments involves strain 401 localization within an anastomosing three-dimensional network of fault segments 402 (Escartín et al., 2017). A fault structure reminiscent of an anastomosing ductile shear 403 zone, exposed structurally beneath the projection of the detachment surface, has also been 404 proposed for the Atlantis Massif OCC (Karson et al., 2006). Many normal faults on the 405 continents are corrugated, and are thought to form by various mechanisms including re406 activation of pre-existing faults and fractures, or progressive breakthrough of originally 407 segmented (i.e. en echelon) fault networks (e.g. Ferrill et al., 1999; Jackson and 408 McKenzie, 1999). In this model, small, individual rupture segments propagate laterally 409 until they overlap, and fault tips eventually propagate along curved paths to intersect and 410 link up with adjacent en echelon fault segments (Candela and Renard, 2012; Childs et al., 411 1995; Peacock, 2002). The resulting network of linked fault segments generates an 412 overall scallop-shaped fault surface, with cuspate ridges that correspond to fault segment 413 intersections (Ferrill et al., 1999). This process of fault segment linkage occurs in three 414 dimensions. In the cross-fault direction, the network of slip planes occupies a finite 415 thickness and is strongly layered. Intersections between slip planes delineate phacoidal 416 blocks that are highly elongated in the direction of extension and show a range of along417 strike dimensions (Figure 10). When this complex detachment zone becomes exposed at 418 the seafloor, the well-preserved phacoidal blocks imprint a subtle topography on the core 419 complex dome, with amplitudes $<10 \mathrm{~m}$ and wavelengths 1-100 m (Figure 7).

421 This model can be tested against a number of key observations. First, the occurrence of 422 corrugations with wavelengths ranging from centimeters to hundreds of meters (Figures 2 423 and 6) can be explained by linkage of fault segments over a spectrum of length scales, 424 without the requirement for ad-hoc small-scale rheological heterogeneities. Since 425 corrugated faults are also found in continental settings, where rheological contrasts 426 cannot be explained by magmatism or serpentinization (although lithology and hydration 
427 contrasts may play a role), this hypothesis is applicable to fault surfaces in a wide range

428 of settings.

430 Recent seismic reflection images have revealed corrugations along the Costa Rica 431 subduction zone megathrust (Edwards et al., 2018). These corrugations are observed to 432 initiate within hundreds of meters of the up-dip extent of the megathrust, and extend 433 down-dip to $\sim 1.4 \mathrm{~km}$ below seafloor, with lengths of $\sim 4-6 \mathrm{~km}$ measured along the fault 434 plane. Corrugations are spaced $\sim 200 \mathrm{~m}$ apart and extend $1 \mathrm{~km}$ or more, and considering 435 the limited ability of seismic reflection images to resolve these structures, are comparable 436 in scale to those at OCCs presented here. Hence despite subduction zone rocks 437 presumably not having significant pre-existing ductile deformation fabrics (as expected at 438 OCCs), they can still give rise to corrugations. The mechanism of strain localization 439 leading to corrugated detachment surfaces may therefore apply to other settings such as 440 subduction zones, further suggesting that corrugation development may be a common by441 product of brittle strain localization that is largely insensitive to lithology and 442 deformation history. Corrugations on oceanic detachment faults therefore may not reflect 443 a unique deformational process, but instead a greater propensity to preserve pristine fault 444 surfaces. This enhanced preservation is due to the relative inefficiency of erosion 445 inferred for young oceanic crust near spreading centers (Olive et al., 2017).

\section{Implications for brittle processes during detachment fault growth}

450 If OCC corrugations do reflect a complex mode of strain localization through interwoven 451 fault segments, it is likely that the resulting phacoidal texture develops over a finite 452 thickness interval within the fault zone, i.e., within a finite depth range below the 453 seafloor. We refer to this portion of the fault as the corrugation factory, to highlight the 454 idea that fault materials enter this zone with pre-existing ductile fabrics (e.g. foliations 455 and lineations) or loosely connected crack networks, and emerge from it with a fully456 developed anastomosed structure (Figure 10). We speculate that pre-existing ductile 457 fabrics may influence the final anastomosed fault character, however since corrugations 458 are present in continental faults and in subduction zones where ductile deformation is 459 unlikely or of limited importance, pre-existing fabrics may not be a requirement. The 
460 corrugation factory must lie within the brittle portion of the oceanic lithosphere, which 461 corresponds to temperatures below $\sim 600^{\circ} \mathrm{C}$ (Hirth et al., 1998). Microearthquakes, a 462 manifestation of active brittle deformation, are known to occur down to depths of $\sim 10 \mathrm{~km}$ 463 near oceanic detachment faults (DeMartin et al., 2007; Parnell-Turner et al., 2017). This 464 observation provides a plausible down-dip limit for the onset of corrugation formation.

466 Morphological considerations, however, can help place more stringent constraints on the 467 location of the corrugation factory along active detachment fault systems. In the case of 468 the $13^{\circ} 20^{\prime} \mathrm{N}$ OCC, spectral analysis reveals no significant change in corrugated seafloor 469 texture along the direction of extension within $\sim 5 \mathrm{~km}$ of the hanging-wall cutoff (Figure 470 9a). In other words, increased slip on the detachment did not result in a significant change 471 in roughness, which is contrary to reported interpretations from much shorter-offset 472 continental normal faults (e.g., Sagy et al., 2007). Our findings suggest that the fault 473 rocks exposed in the corrugated terrain have all experienced the same degree of strain, 474 and thus acquired the same fabric. This hypothesis can be explained by a simple model 475 illustrated in Figure 10d, which shows that the total strain accumulated within a shear 476 zone of finite downdip extent, $L$, no longer depends on its accumulated offset once this 477 offset exceeds $L$. Only fault rocks located close to the breakaway - which have not 478 traveled through the entire extent of the corrugation factory- would show a gradient in 479 recorded strain (and potentially fabric) in the slip direction (Figure 10d). At $13^{\circ} 20^{\prime} \mathrm{N}$, 480 such rocks may be located beneath the heavily mass-wasted terrain that lies within 5 to 9 $481 \mathrm{~km}$ of the hanging-wall cutoff and would therefore be inaccessible to direct observation. 482 However, since fault rocks located as close as $\sim 4 \mathrm{~km}$ to the breakaway exhibit the same 483 roughness as subsequently exposed fault rocks, the downdip extent of the corrugation 484 factory could not have exceeded $\sim 4 \mathrm{~km}$, at least during the early stages for fault 485 exhumation.

487 According to the fault geometry constrained by microseismicity and proposed by Parnell488 Turner et al. (2017), the footwall rocks presently exposed at the $13^{\circ} 20^{\prime} \mathrm{N}$ hanging-wall 489 cutoff likely originated at depths of $\sim 8 \mathrm{~km}$ below seafloor. This means that the 490 corrugation factory must lie at shallower levels, and also account for less than $\sim 25 \%$ of 491 the sub-seafloor extent of the detachment fault surface in the brittle domain. It is 492 therefore likely that corrugations originate within the uppermost $\sim 4 \mathrm{~km}$ of the brittle 
493 domain. Interestingly, corrugations imaged on the Costa Rica megathrust are well 494 developed at depths as shallow as $\sim 1.4 \mathrm{~km}$ below seafloor (Edwards et al., 2018). This 495 observation suggests that the strain accumulated by megathrust rocks at the initiation of 496 burial (i.e., at low temperature and confining pressure) is sufficient to generate 497 corrugations. At $13^{\circ} 20^{\prime} \mathrm{N}$, the uppermost $4 \mathrm{~km}$ of the detachment does not presently host 498 microearthquakes (Parnell-Turner et al., 2017), but may occasionally rupture during 499 larger, teleseismically-detected events (Craig and Parnell-Turner, 2017). Strong 500 microseismicity however occurs at depths of 4-6 km and 7-12 km below seafloor at the 501 TAG and $13^{\circ} 20^{\prime} \mathrm{N}$ detachments, respectively (deMartin et al., 2007; Parnell-Turner et al., 502 2017). While the corrugation factory clearly could not have been situated at those depths 503 when the $13^{\circ} 20^{\prime} \mathrm{N}$ detachment formed, it is possible that it has deepened through time, as 504 the entire detachment system matured.

506 Detachment microearthquakes typically have local magnitudes $\left(M_{L}\right)$ ranging between 0.5 507 and 1.5 (DeMartin et al., 2007; Parnell-Turner et al., 2017). Assuming that a fault patch 508 can be approximated by a circular crack, the rupture area, $a$, associated with an 509 earthquake can be written in terms of seismic moment, $M_{0}$, as

$$
a=\sqrt[3]{\frac{7}{16} \frac{M_{0}}{\Delta \sigma}}
$$

512 where $\Delta \sigma$ is stress drop (assumed to be $3 \mathrm{MPa}$ ), and $M_{0}$ is related to $M_{L}$ by

$$
\log _{10} M_{0}=1.5 M_{L}+16.1
$$

516 Microearthquakes with typical $M_{L}$ ranging between 0.5 and 1.5 would therefore be 517 expected to occur on rupture patches $20-30 \mathrm{~m}^{2}$ in area, or 5-6 $\mathrm{m}$ in diameter. This 518 characteristic rupture diameter is smaller than the areal extent of individual corrugations 519 revealed by the microbathymetric data. We therefore propose that the microearthquake 520 activity represents the breaking of new slip planes (below $4 \mathrm{~km}$ beneath the seafloor) that 521 will eventually coalesce at shallower depths (above $4 \mathrm{~km}$ ) within the corrugation factory 522 to form the final anastomosing fabric, which includes structures on length scales from 523 centimeters to hundreds of meters. We thus speculate that the corrugation factory in the 524 active $13^{\circ} 20^{\prime} \mathrm{N}$ and TAG detachments must have been at depths $<4 \mathrm{~km}$ during the early 
525 stages of fault slip. Its modern-day depth window may begin as shallow as $\sim 2 \mathrm{~km}$ based

526 on geological sampling (Bonnemains et al., 2016), and may also now overlap with the

527 depth extent of microearthquakes at depths $>4 \mathrm{~km}$ (Parnell-Turner et al., 2017).

\section{6. Conclusions}

531 We have compiled and analyzed $2 \mathrm{~m}$ resolution near-bottom bathymetric data acquired 532 by AUV over five corrugated oceanic detachment fault surfaces along the Mid-Atlantic 533 Ridge. Despite having variable footwall lithology and recording different amounts of slip, 534 we find that the geometry of corrugations at the five sites is remarkably consistent: 535 spacing is typically $50-250 \mathrm{~m}$, and slip-parallel lengths are mostly $100-500 \mathrm{~m}$ for 536 example. We also find that corrugations have well-defined ends, and do not extend across 537 the entire exposed fault surface. Spectral analysis shows that fault surfaces at the five 538 sites have comparable levels of roughness, and are not self-similar or self-affine. We find 539 that fault roughness does not vary as a function of slip, implying that for the portion of 540 fault surfaces observed here, the process of fault nucleation and growth is relatively 541 constant as extension proceeds. This result is in contrast to findings for terrestrial normal 542 faults, probably because the surfaces that record the comparable early stages of slip at 543 oceanic detachments studied here are hidden beneath the breakaway zone.

545 We have used our observations to evaluate three hypotheses for corrugation genesis. The 546 continuous casting hypothesis is inconsistent with earlier seafloor observations of the 547 three-dimensional character of the corrugated fault zone, which may be hundreds of 548 meters thick (Bonnemains et al., 2017; Escartín et al., 2017). This hypothesis is also 549 inconsistent with the observation that corrugations are finite in length, and therefore 550 cannot be formed 'continuously'. We use simple thermal scaling arguments to show that 551 the varying brittle-ductile depth hypothesis cannot explain the observed length and 552 spacing of corrugations. We find that any thermally-driven rheological anomaly would 553 dissipate long before a corrugation could form, unless unfeasibly high spreading rates are 554 invoked.

556 We conclude that the strain localization hypothesis, where a network of small rupture 557 patches coalesces into an uneven fault surface within a corrugation factory, best explains 
558 presence and geometry of corrugated fault surfaces on oceanic detachments. This 559 corrugation factory likely initiated at depths shallower than $\sim 4 \mathrm{~km}$ when the $13^{\circ} 20^{\prime} \mathrm{N}$ and

560 TAG detachments first formed. It may now lie at depths closer to $\sim 4 \mathrm{~km}$ and overlap with

561 the microseismically-active portion of these faults, where new slip surfaces initiate before

562 eventually coalescing over a few $\mathrm{km}$ along the fault. This hypothesis is not dependent

563 upon thermal or rheological fault variability, nor on pre-existing deformation fabrics, and

564 may thus be applicable to faults in terrestrial and subduction zone settings, where

565 corrugations are also documented. Hence fracture linkage and displacement can lead to

566 corrugations on fault surfaces regardless of the setting.

\section{Acknowledgements}

570 Near-bottom bathymetric data acquisition was supported by National Science Foundation

571 (NSF) grant OCE-1155650, GEOMAR, CNRS, IFREMER, and INSU. Mapping at TAG

572 was supported by Project 604500 "Blue Mining" under the EU $7^{\text {th }}$ Framework

573 Programme. RPT was supported by NSF grant OCE-1736547. We thank the crew and

574 science parties of RV Knorr, RV Meteor and N/O Pourquoi Pas?, and the engineering

575 teams of AUVs Abyss and Sentry for their hard work and professionalism. We are

576 grateful for the detailed and constructive comments from two anonymous reviewers.

577 Data from KN210-05 and ODEMAR cruises are available at doi:10.7284/900548 and

578 doi:10.17600/13030070, respectively. 


\section{References}

Blackman, D.K., Ildefonse, B., John, B.E., Ohara, Y., Miller, D.J., Abe, N., Abratis, M., Andal, E.S., Andreani, M., Awaji, S., Beard, J.S., Brunelli, D., Charney, A.B., Christie, D.M., Collins, J.A., Delacour, A.G., Delius, H., Drouin, M., Einaudi, F., Escartín, J., Frost, B.R., Green, G.F., Fryer, P.B., Gee, J.S., Godard, M., Grimes, C.B., Halfpenny, A., Hansen, H.E., Harris, A.C., Tamura, A., Hayman, N., Hellebrand, E., Hirose, T., Hirth, G., Ishimaru, S., Johnson, K.T.M., Karner, G.D., Linek, M., MacLeod, C.J., Maeda, J., Mason, O.U., McCaig, A.M., Michibayashi, K., Morris, A., Nakagawa, T., Nozaka, T., Rosner, M., Searle, R.C., Suhr, G., Tominaga, M., von der Handt, A., Yamasaki, T., Zhao, X., 2011. Drilling constraints on lithospheric accretion and evolution at Atlantis Massif, Mid-Atlantic Ridge $30^{\circ}$ N. J. Geophys. Res. 116. doi:10.1029/2010JB007931

Bonnemains, D., Escartín, J., Mével, C., Andreani, M., Verlaguet, A., 2017. Pervasive silicification and hangingwall overplating along the $13^{\circ} 20^{\prime} \mathrm{N}$ oceanic detachment fault (Mid-Atlantic Ridge). Geochem. Geophys. Geosyst 18, 2028-2053. doi:10.1002/2017GC006846

Bonnemains, D., Verlaguet, A., Escartín, J., Mevel, C., Andreani, M., 2016. Hydrothermal circulation along oceanic detachment fault: Constraints on the nature and conditions of syntectonic silicification at the $13^{\circ} 20^{\prime} \mathrm{N}$ oceanic core complex (Mid-Atlantic ridge). Abstr. T33A-3001 Present. 2016 Fall Meet. AGU, San Fr. Calif. 12-16 Dec.

Brown, S.R., 1987. A note on the description of surface roughness using fractal dimension. Geophys. Res. Lett. 14, 1095-1098. doi:10.1029/GL014i011p01095

\section{Candela, T., Renard, F., 2012. Segment linkage process at the origin of slip surface} roughness: Evidence from the Dixie Valley fault. J. Struct. Geol. 45, 87-100. doi:10.1016/j.jsg.2012.06.003

Cann, J.R., Blackman, D.K., Smith, D.K., McAllister, E., Janssen, B., Mello, S., Avgerinos, E., Pascoe, A.R., Escartín, J., 1997. Corrugated slip surfaces formed at ridge-transform intersections on the Mid-Atlantic Ridge. Nature 385, 329-332. Data on the R/V Maurice Ewing. Mar. Geophys. Res. 18, 631-650. 
Childs, C., Watterson, J., Walsh, J.J., 1995. Fault overlap zones within developing normal fault systems. J. Geol. Soc. 152, 535-549.

Craig, T.J., Parnell-Turner, R., 2017. Depth-varying seismogenesis on an oceanic detachment fault at $13^{\circ} 20^{\prime} \mathrm{N}$ on the Mid-Atlantic Ridge. Earth Planet. Sci. Lett. 479, 60-70. doi:10.1016/j.eps1.2015.01.026

DeMartin, B.J., Sohn, R.A., Canales, J.P., Humphris, S.E., 2007. Kinematics and geometry of active detachment faulting beneath the Trans-Atlantic Geotraverse (TAG) hydrothermal field on the Mid-Atlantic Ridge. Geology 35, 711-714.

$$
\text { doi:10.1130/G23718A.1 }
$$

Edwards, J.H., Kluesner, J.W., Silver, E.A., Brodsky, E.E., Brothers, D.S., Bangs, N.L., Kirkpatrick, J.D., Wood, R., Okamoto, K., 2018. Corrugated megathrust revealed offshore from Costa Rica. Nat. Geosci. 11, 197-202. doi:10.1038/s41561-018-00614

Escartín, J., Canales, J.P., 2011. Detachments in oceanic lithosphere: Deformation, magmatism, fluid flow, and ecosystems. Eos Trans., AGU 92, 31.

Escartín, J., Petersen, S., Bonnemains, D., Cannat, M., Andreani, M., Bezos, A., Chavagnac, V., Choi, Y., Godard, M., Haaga, K., Hamelin, C., Ildefonse, B., Jamieson, J., John, B.E., Leleu, T., MacLeod, C.J., Massot-Campos, M., Nomikou, P., Olive, J.A., Paquet, M., Rommevaux, C., Rothenbeck, M., Steinfuhrer, A., Tominaga, M., Triebe, L., Garcia, R., Campos, R., 2017. Tectonic structure, evolution, and the nature of oceanic core complexes and their detachment fault zones (1320’ N and $13^{\circ} 30^{`} \mathrm{~N}$, Mid Atlantic Ridge). Geochem. Geophys. Geosyst 18. doi:10.1002/2016GC006775

Escartín, J., Smith, D.K., Cann, J.R., Schouten, H., Langmuir, C.H., Escrig, S., 2008. Central role of detachment faults in accretion of slow-spreading oceanic lithosphere. Nature 455, 790-794. doi:10.1038/nature07333

Ferrill, D.A., Stamatakos, J.A., Sims, D., 1999. Normal fault corrugation: implications for growth and seismicity of active normal faults. J. Struct. Geol. 21, 1027-1038. doi:10.1016/S0191-8141(99)00017-6

Fletcher, J.M., Bartley, J.M., 1994. Constrictional strain in a non-coaxial shear zone: implications for fold and rock fabric development, central Mojave metamorphic core complex, California. J. Struct. Geol. 16, 555-570. doi:10.1016/01918141(94)90097-3 
646

Hirth, G., Escartín, J., Lin, J., 1998. The Rheology of the Lower Oceanic Crust: Implications for Lithospheric Deformation at Mid-Ocean Ridges, in: Faulting and Magmatism at Mid-Ocean Ridges, Geophysical Monograph 106. American Geophysical Union, pp. 291-303. doi:10.1029/GM106p0291

Jackson, J., McKenzie, D.P., 1999. A hectare of fresh striations on the Arkitsa Fault, central Greece. J. Struct. Geol. 21, 1-6. doi:10.1016/S0191-8141(98)00091-1

John, B.E., 1987. Geometry and evolution of a mid-crustal extensional fault system: Chemehuevi Mountains, southeastern California. Geol. Soc. Spec. Pub. 313-335. doi:10.1144/GSL.SP.1987.028.01.20

Karson, J.A., 1999. Geological investigation of a lineated massif at the Kane Transform Fault: implications for oceanic core complexes. Philos. Trans. R. Soc. Lond. A 357, 713-736. doi:10.1098/rsta.1999.0350

Karson, J.A., Dick, H.J.B., 1983. Tectonics of ridge-transform intersections at the Kane fracture zone. Mar. Geophys. Res. 6, 51-98. doi:10.1007/BF00300398

Karson, J.A., Früh-Green, G., Kelley, D.S., Williams, E.A., Yoerger, D., Jakuba, M., 2006. Detachment shear zone of the Atlantis Massif core complex, Mid-Atlantic Ridge, $30^{\circ}$ N. Geochem. Geophys. Geosyst 7. doi:10.1029/2005GC001109

Karson, J.A., Rona, P.A., 1990. Block-tilting, transfer faults, and structural control of magmatic and hydrothermal processes in the TAG area, Mid-Atlantic Ridge $26^{\circ} \mathrm{N}$. Geol. Soc. Am. Bull. 102, 1635-1645. doi:10.1130/00167606(1990)102<1635:BTTFAS $>2.3 . C O ; 2$

Lalou, C., Reyss, J.-L., Brichet, E., Rona, P.A., Thompson, G., 1995. Hydrothermal activity on a $10^{5}$-year scale at a slow spreading ridge, TAG hydrothermal field, Mid-Atlantic Ridge 26N. J. Geophys. Res. 100, 17,855-17,862. doi:10.1029/95jb01858

MacLeod, C.J., Escartín, J., Banerji, D., Banks, G.J., Gleeson, M., Irving, D.H.B., Lilly, R.M., McCaig, A.M., Niu, Y., Allerton, S., Smith, D.K., 2002. Direct geological evidence for oceanic detachment faulting: The Mid-Atlantic Ridge, $1545^{\prime} \mathrm{N}$. Geology 30, 879-882. doi:10.1130/0091-7613(2002)030<0879

MacLeod, C.J., Searle, R.C., Murton, B.J., Casey, J.F., Mallows, C., Unsworth, S.C., Achenbach, K.L., Harris, M., 2009. Life cycle of oceanic core complexes. Earth Planet. Sci. Lett. 287, 333-344. doi:10.1016/j.eps1.2009.08.016

Malamud, B.D., Turcotte, D.L., 1999. Self-affine time series: 1. Generation and analyses. 
Adv. Geophys. 40, 1-90.

Mallows, C., Searle, R.C., 2012. A geophysical study of oceanic core complexes and surrounding terrain, Mid-Atlantic Ridge $13^{\circ} \mathrm{N}-14^{\circ} \mathrm{N}$. Geochem. Geophys. Geosyst 13. doi:10.1130/G39232.1

Olive, J.-A., Parnell-Turner, R., Escartín, J., Smith, D.K., Petersen, S., 2017. Controls on the Seafloor Exposure of Detachment Fault Surfaces. Abstract T33D-0750 presented at 2017 AGU Fall Meeting, New Orleans, LA, 11-15 Dec.

Parnell-Turner, R., Cann, J.R., Smith, D.K., Schouten, H., Yoerger, D., Palmiotto, C., Zheleznov, A., Bai, H., 2014. Sedimentation rates test models of oceanic detachment faulting. Geophys. Res. Lett. 41. doi:10.1002/2014GL061555

Parnell-Turner, R., Schouten, H., Smith, D.K., 2016. Tectonic Structure of the MidAtlantic Ridge near $16^{\circ} 30^{\prime}$ N. Geochem. Geophys. Geosyst doi:

\subsection{2/2016GC006514.}

Parnell-Turner, R., Sohn, R.A., Peirce, C., Reston, T.J., Macleod, C.J., Searle, R.C., Simão, N., 2017. Oceanic Detachment Faults Generate Compression in Extension. Geology 45, 932-926. doi:10.1130/G39232.1

Peacock, D.C.P., 2002. Propagation, interaction and linkage in normal fault systems. Earth-Science Rev. 58, 121-142. doi:10.1016/S0012-8252(01)00085-X

Power, W.L., Tullis, T.E., 1991. Euclidean and fractal models for the description of rock surface roughness. J. Geophys. Res. 96, 415. doi:10.1029/90JB02107

Power, W.L., Tullis, T.E., Weeks, J.D., 1988. Roughness and wear during brittle faulting. J. Geophys. Res. 93, 15,268-15,278. doi:10.1029/JB093iB12p15268

Rona, P.A., Hannington, M.D., Raman, C.V., Thompson, G., Tivey, M.K., Humphris, S.E., Lalou, C., Petersen, S., 1993. Active and relict sea-floor hydrothermal mineralization at the TAG hydrothermal field, Mid-Atlantic Ridge. Econ. Geol. 88, 1989-2017.

Rona, P.A., Klinkhammer, G., Nelsen, T.A., Trefry, J.H., Elderfield, H., 1986. Black smokers, massive sulphides and vent biota at the Mid-Atlantic Ridge. Nature 321, 33-37. doi:10.1038/321033a0

Sagy, A., Brodsky, E.E., Axen, G.J., 2007. Evolution of fault-surface roughness with slip. Geology 35, 283-286. doi:10.1130/G23235A.1

Schroeder, T., John, B.E., 2004. Strain localization on an oceanic detachment fault system, Atlantis Massif, $30^{\circ} \mathrm{N}$, Mid-Atlantic Ridge. Geochem. Geophys. Geosyst 5. 
doi:10.1029/2004GC000728

713 Scott, R.B., Rona, P.A., McGregor, B.A., 1974. The TAG hydrothermal field. Nature 251, 301-302. doi:10.1038/252497a0

715 Searle, R.C., Cannat, M., Fujioka, K., Mevel, C., Fujimoto, H., Bralee, A., Parson, L., 2003. FUJI Dome: A large detachment fault near $64^{\circ} \mathrm{E}$ on the very slow-spreading southwest Indian Ridge. Geochem. Geophys. Geosyst 4.

$$
\text { doi:10.1029/2003GC000519 }
$$

Sheather, S.J., Jones, M.C., 1991. A Reliable Data-Based Bandwidth Selection Method for Kernel Density Estimation. J. R. Stat. Soc. B 53, 683-690.

Smith, D.K., Escartín, J., Schouten, H., Cann, J.R., 2008. Fault rotation and core complex formation: Significant processes in seafloor formation at slow-spreading mid-ocean ridges (Mid-Atlantic Ridge, $13^{\circ}-15^{\circ} \mathrm{N}$ ). Geochem. Geophys. Geosyst 9. doi:10.1029/2007GC001699

Smith, D.K., Schouten, H., Dick, H.J.B., Cann, J.R., Salters, V., Marschall, H., Ji, F., Yoerger, D., Sanfilippo, A., Parnell-Turner, R., Palmiotto, C., Zheleznov, A., Bai, H., Junkin, W., Urann, B.M., Dick, S., Sulanowska, M., Lemmond, P., Curry, S., 2014. Development and evolution of detachment faulting along $50 \mathrm{~km}$ of the MidAtlantic Ridge near $16.5^{\circ}$ N. Geochem. Geophys. Geosyst 15, 4692-4711. doi:10.1002/2014GC005563

Spencer, J.E., 1999. Geologic continuous casting below continental and deep-sea detachment faults and at the striated extrusion of Sacsayhuamán, Peru. Geology 27, 327-330. doi:10.1130/0091-7613(1999)027<0327

Thomson, D.J., 1982. Spectrum estimation and harmonic analysis. Proc. IEEE 70, 10551096. doi:10.1109/PROC.1982.12433

Tivey, M.A., Schouten, H., Kleinrock, M.C., 2003. A near-bottom magnetic survey of the Mid-Atlantic Ridge axis at $26^{\circ} \mathrm{N}$ : Implications for the tectonic evolution of the TAG segment. J. Geophys. Res. 108, 1-13. doi:10.1029/2002JB001967

Tucholke, B.E., Behn, M.D., Buck, W.R., Lin, J., 2008. Role of melt supply in oceanic detachment faulting and formation of megamullions. Geology 36, 455. doi:10.1130/G24639A.1

Tucholke, B.E., Lin, J., Kleinrock, M.C.C., 1998. Megamullions and mullion structure defining oceanic metamorphic core complexes on the Mid-Atlantic Ridge. J. Geophys. Res. 103, 9857-9866. 
745 Turcotte, D.L., Schubert, G., 2002. Geodynamics. Cambridge University Press.

746 doi: $10.1017 /$ CBO9780511807442

747 Whitney, D.L., Teyssier, C., Rey, P., Roger Buck, W., 2013. Continental and oceanic $748 \quad$ core complexes. Bull. Geol. Soc. Am. 125, 273-298. doi:10.1130/B30754.1

749 Zonenshain, L.P., Kuzmin, M.I., Lisitsin, A.P., Bogdanov, Y.A., Baranov, B. V., 1989.

750 Tectonics of the Mid-Atlantic rift valley between the TAG and MARK areas (26-

$\left.75124^{\circ} \mathrm{N}\right)$ : Evidence for vertical tectonism. Tectonophysics 159, 1-23.

752 doi:10.1016/0040-1951(89)90167-4

753

754 


\section{$755 \quad$ Figures}

756

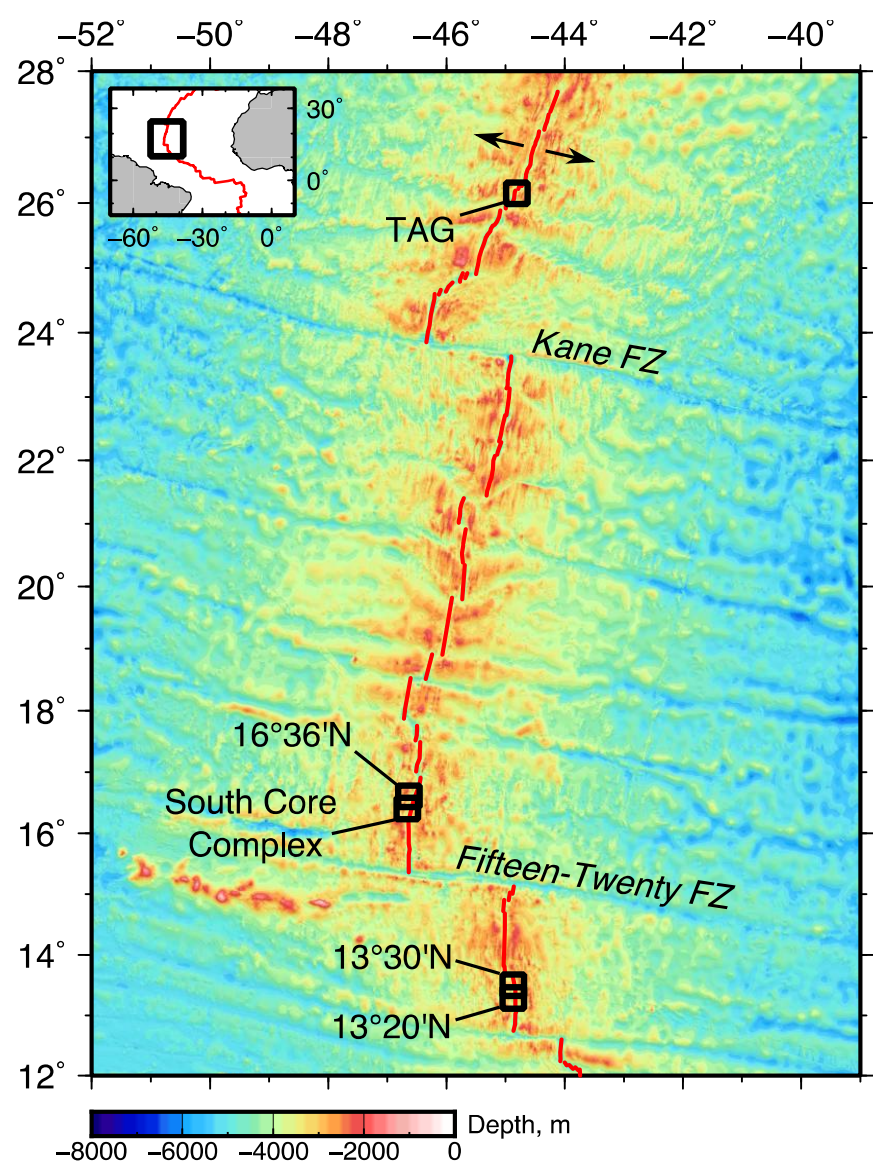

760 Figure 1. Location of five studied oceanic detachments along the northern Mid-Atlantic

761 Ridge (black boxes), surveyed with near-bottom AUV dives; red line is ridge axis; arrows 762 show spreading direction; selected fracture zones (FZ) labeled. Inset: black box shows 763 location of main panel; red line is ridge axis. 

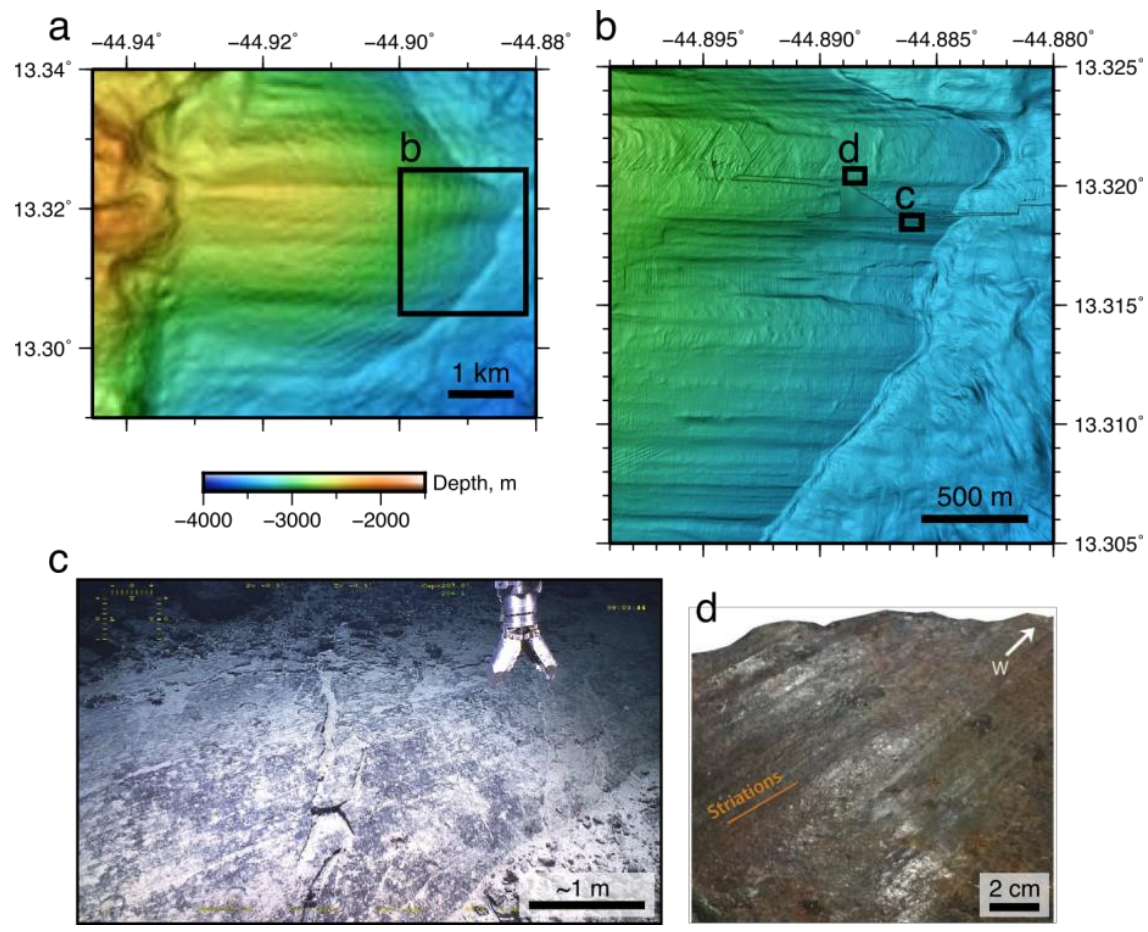

768 Figure 2. Corrugated fault surface imaged at kilometer to centimeter scales, at $13^{\circ} 20^{\prime} \mathrm{N}$.

769 a) Shipboard bathymetric data, gridded at 40 m node spacing (Escartín et al., 2017). Note

770 corrugations on hundreds of meters scale, on top of larger kilometer-scale domed fault

771 surface. b) Bathymetric data acquired near-bottom by AUV (Escartín et al., 2017),

772 location shown in (a). Note corrugations visible at wavelengths of tens of meters. c)

773 Seafloor image of striated fault surface (Escartín et al., 2017), location shown in (b), on

774 flank of a bathymetric corrugation. Note that fault striations are spaced $<1 \mathrm{~m}$ apart, and

775 are sub-horizontal, oriented parallel to displacement and to corrugations in (b). d)

776 Macrophotograph of fault rock (sample ODM217), containing ultramafic clasts, showing

$777 \mathrm{~cm}$ - to mm-scale spreading-parallel striations (Bonnemains et al., 2017); sampling 778 location shown in (b). 

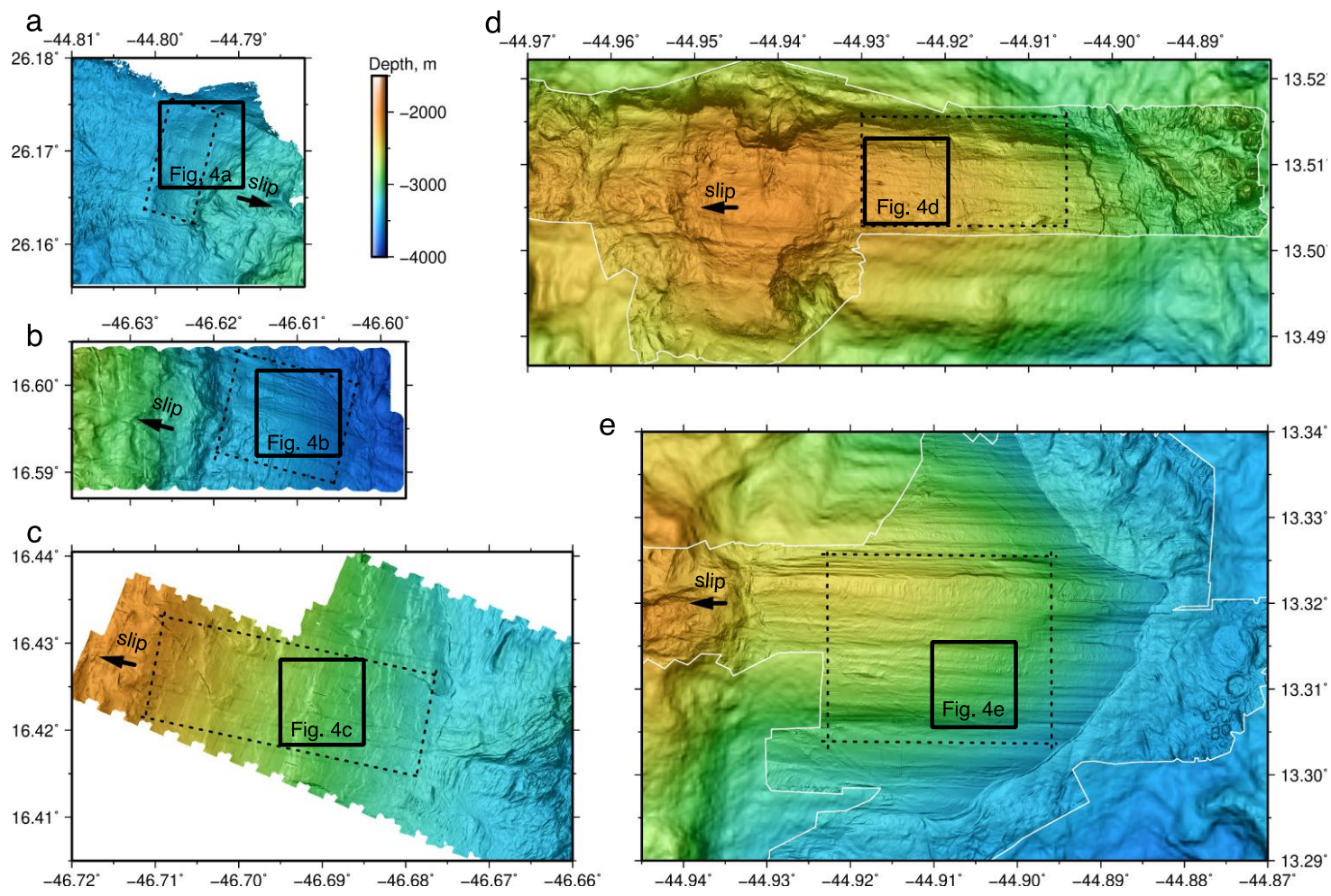

Figure 3. Near-bottom multibeam bathymetric surveys over corrugated detachment fault surfaces, acquired during AUV surveys. Data gridded at $\sim 2 \mathrm{~m}$ grid cell size and maps

790 (this study). b) $16^{\circ} 36^{\prime} \mathrm{N}$ (Smith et al., 2014). c) SCC (Smith et al., 2014). d) and e) $7911^{\circ} 30^{\prime} \mathrm{N}$ and $13^{\circ} 20^{\prime} \mathrm{N}$ (Escartín et al., 2017). Arrows show inferred slip direction; solid 792 boxes locate panels in Figure 4; dashed boxes mark area of fault surfaces used to extract 793 profiles and spectra (Figure 7); white lines in (d) and (e) mark AUV survey extents. 


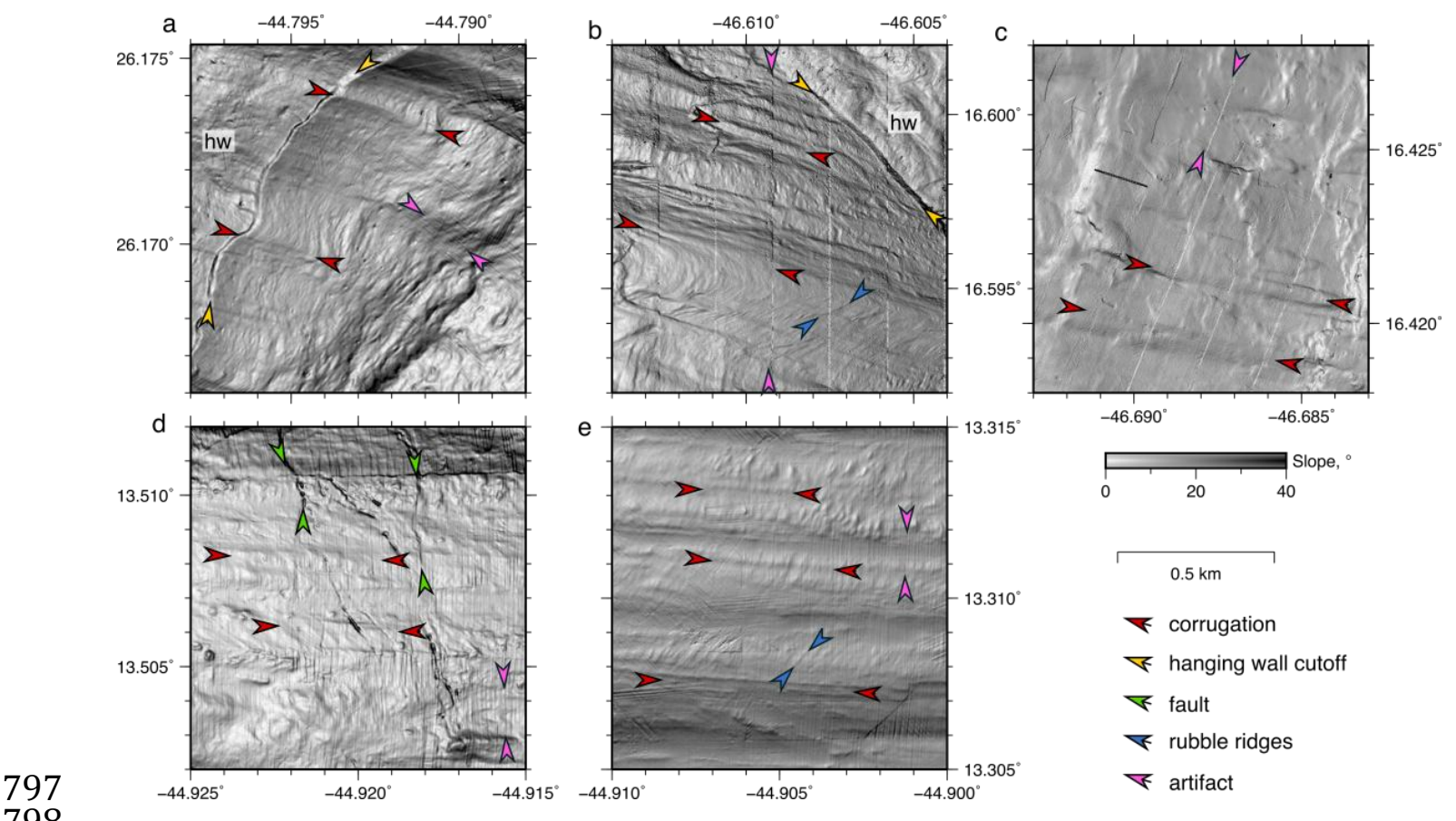

Figure 4. Detailed views of corrugated fault surfaces. Zooms of bathymetric slope 800 plotted at equal scale, with arrows showing hanging-wall cutoff (yellow), corrugation 801 highs (red), rubble ridges (blue), cross-cutting faults (green), and examples of artifacts 802 (pink; note AUV roll artifacts spaced $200 \mathrm{~m}$ apart in (a), (d) and (e), and >1 km-long 803 artifacts along overlap between adjacent swaths in (b) and (c); zoom locations shown in 804 Figure 3. Hanging wall (hw) is marked where visible. a) TAG. b) $16^{\circ} 36^{\prime}$ N. c) SCC. d) $80513^{\circ} 30^{\prime}$ N. e) $13^{\circ} 20^{\prime} \mathrm{N}$.

806

807

808

809

810 

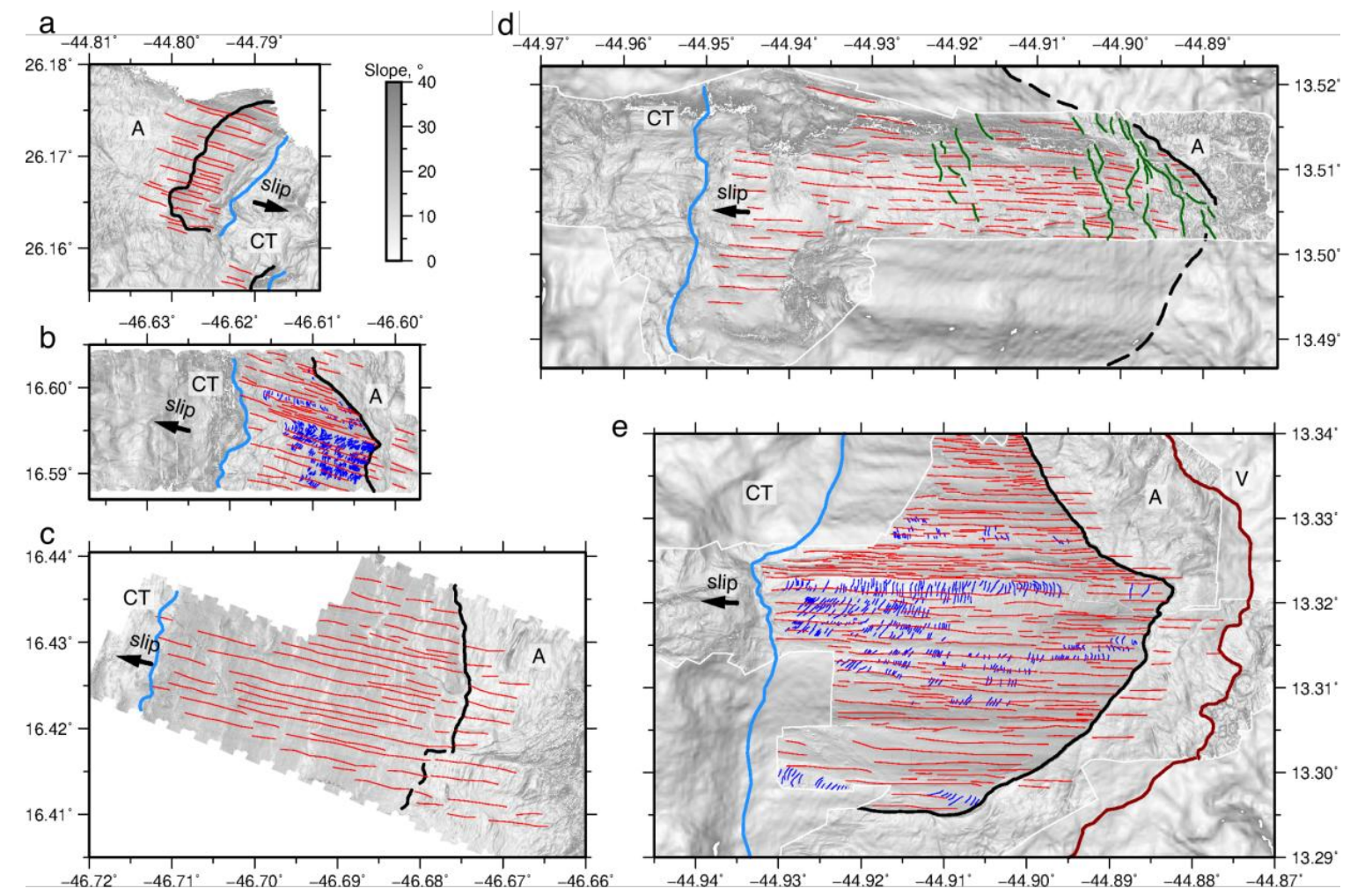

$$
\begin{aligned}
& \text { - corrugations } \quad \text { rubble ridges } \quad \text { inferred faults } \\
& \text { - hanging wall cutoff } \quad \text { volcanic terrain boundary }
\end{aligned}
$$

818 Figure 5. Bathymetric slope maps with interpretation of seafloor features. Red lines are

819 interpreted spreading-parallel corrugations, based on linear relief identified in short-

820 wavelength filtered maps (Supplementary Figure 1); short blue lines are rubble ridges

821 lying on corrugated fault surface; black lines are the hanging-wall cutoff (dashed where

822 uncertain); light blue line marks boundary between corrugated surface and chaotic terrain

823 (CT); dark red line in (e) marks boundary between apron and volcanic terrain (V).

824 Corrugated surfaces are bound on either side by chaotic terrain (CT) and apron (A). a)

825 TAG. b) $16^{\circ} 36^{\prime}$ N. c) SCC. d) $13^{\circ} 30^{\prime}$ N. e) $13^{\circ} 20^{\prime}$ N. 

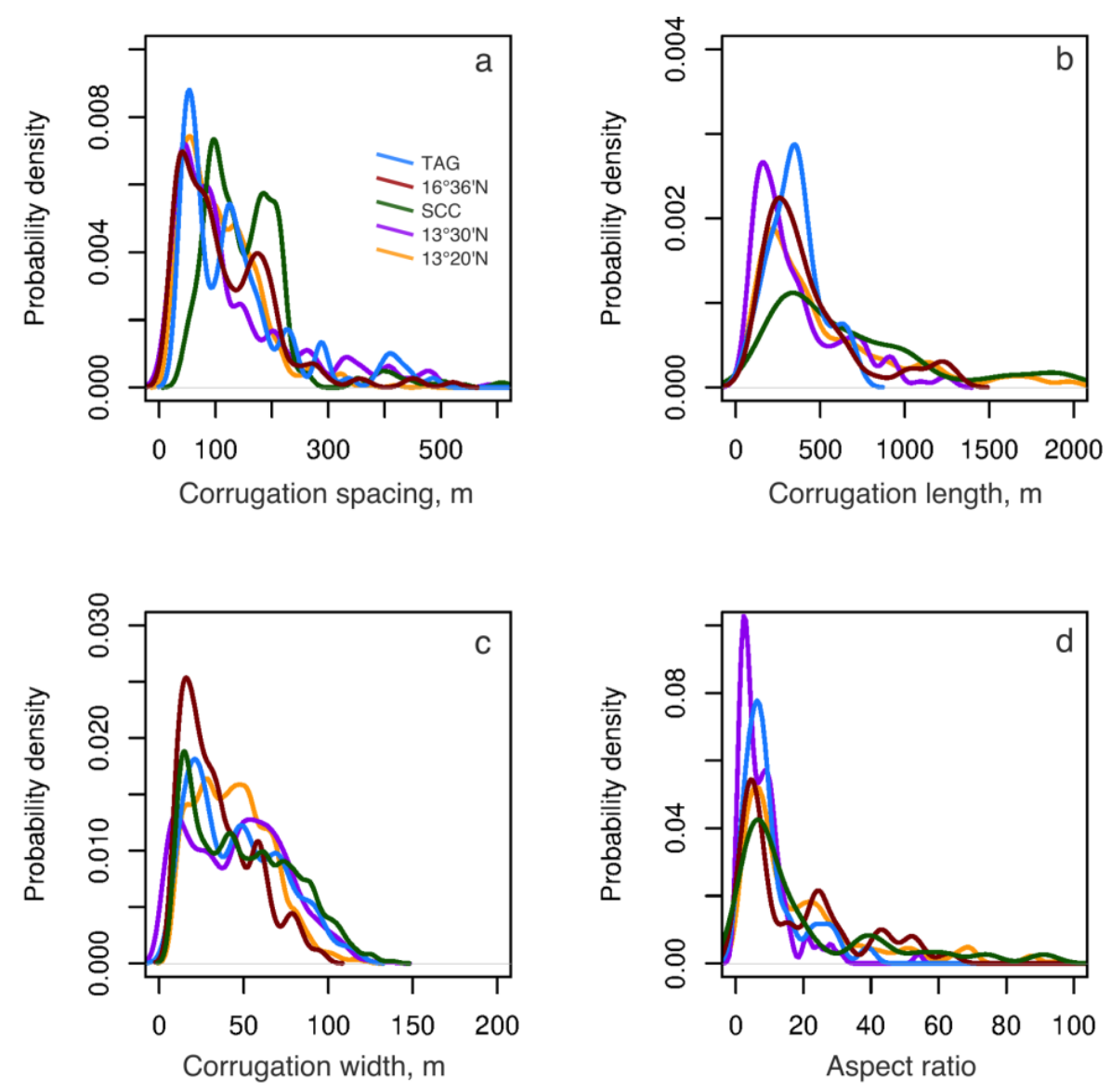

829 Figure 6. Fault surface corrugation statistics. a) Corrugation spacing. Probability density 830 function obtained with kernel density estimation from interpreted corrugations shown in 831 Figure 5; colors indicate location (see key). b) Corrugation length. c) Corrugation width. 832 d) Corrugation aspect ratio defined as corrugation width/length. 

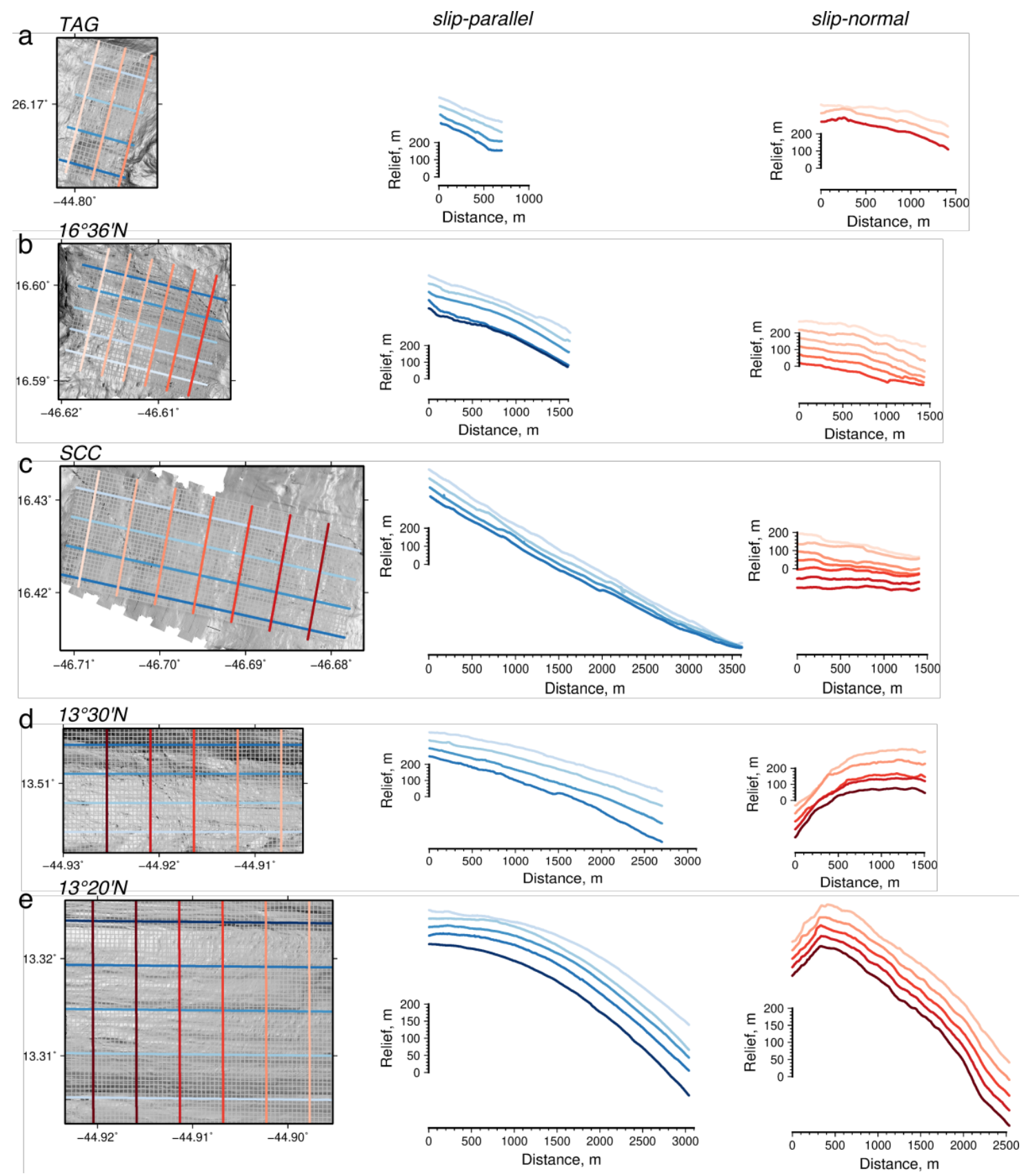

845

846 Figure 7. Bathymetric profiles used for spectral analysis. Left column are slope maps

847 plotted at equal scale, location marked by dashed boxes in Figure 2; gray lines are

848 location of all profiles at $50 \mathrm{~m}$ spacing; blue/red lines are selected slip-parallel and slip-

849 normal profiles, respectively, shown in center and right columns. a) TAG. b) $16^{\circ} 36^{\prime} \mathrm{N}$. c)

850 SCC. d) $13^{\circ} 30^{\prime}$ N. e) $13^{\circ} 20^{\prime} \mathrm{N}$. 

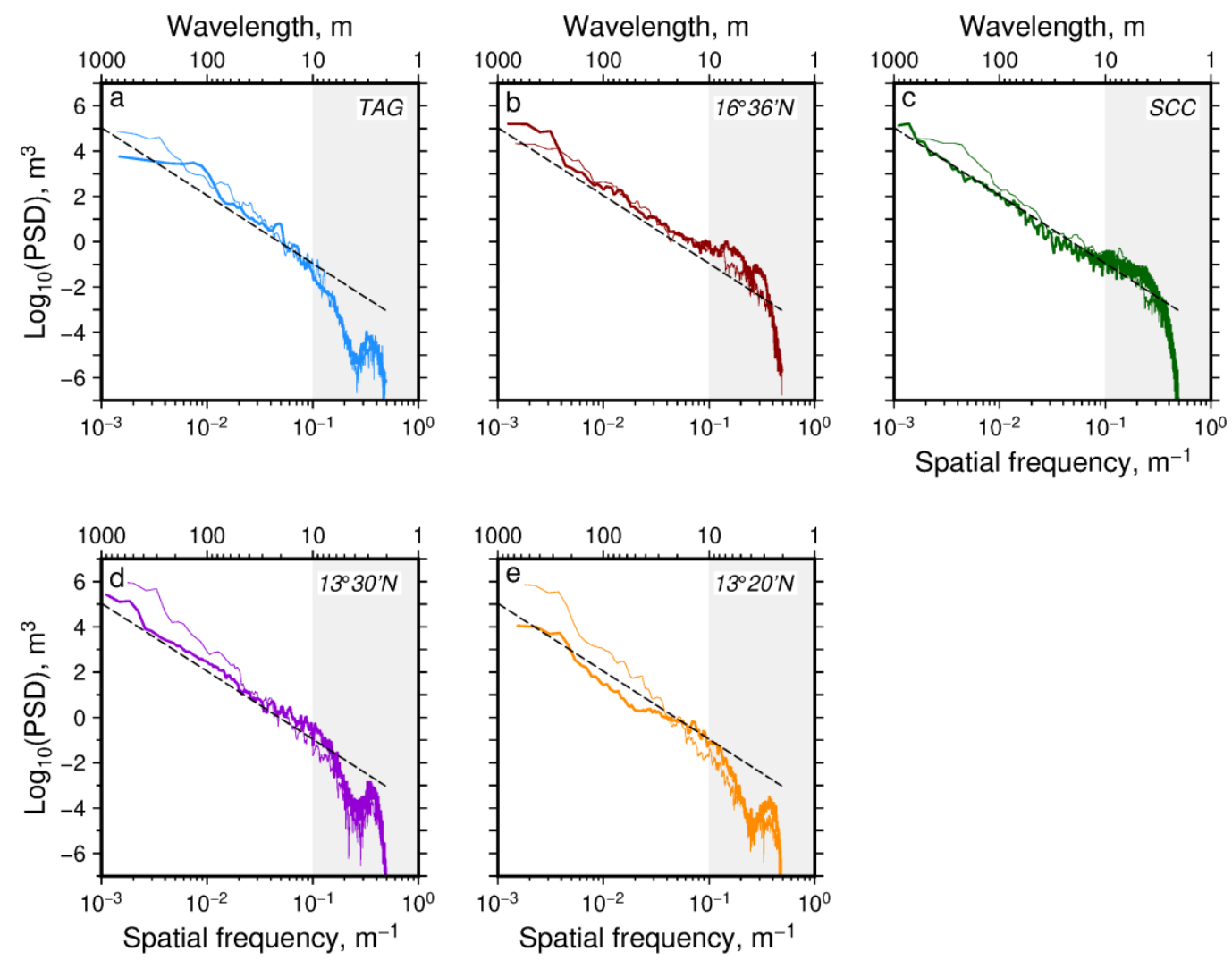

859 Figure 8. Power spectra. Power spectral density of bathymetric profiles from Figure 7;

860 thick/thin lines are spectra from slip-parallel/normal profiles, respectively. Dashed line is 861 slope of spectra of self-similar surface $(\beta=3)$, which is less than or equal to slope of 862 observed spectra in most cases. a) TAG. b) $16^{\circ} 36^{\prime} \mathrm{N}$. c) SCC. d) $13^{\circ} 30^{\prime} \mathrm{N}$. e) $13^{\circ} 30^{\prime} \mathrm{N}$. 

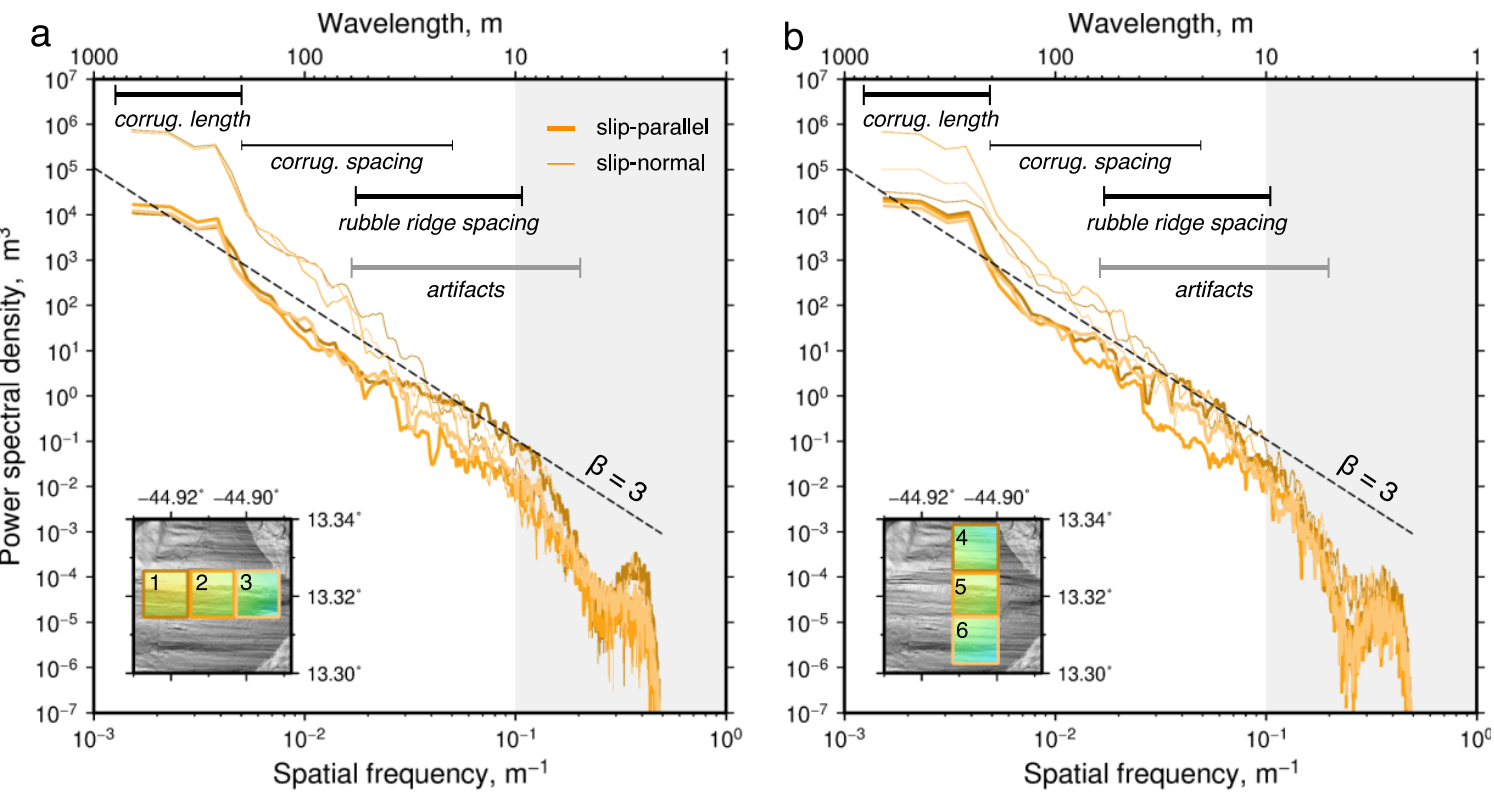

Figure 9. Power spectra along and across $13^{\circ} 20^{\prime} \mathrm{N}$ fault surface. a) Spectra from eastwest sequence of boxes (1.3 x $1.3 \mathrm{~km}$ in size; numbered 1, 2 and 3 in inset map); boxes are portions of fault surface that have experienced progressively more slip. Dark orange, orange and light orange boxes/spectra are boxes 1, 2 and 3, respectively; thick lines are slip-parallel, thin lines are slip-normal. Note increased power for slip-normal profiles at 877 wavelengths of $\sim 20-200 \mathrm{~m}$, agreeing with observed corrugation spacing (thin bar); 878 increased power wavelengths $>200 \mathrm{~m}$ on slip-parallel profiles, matching corrugation 879 length (thick bar); increased power at wavelengths of 10-50 $\mathrm{m}$ for slip-parallel profiles in 880 box 1 matching spacing of rubble ridges (thick bar). Gray bar indicates presence of possible multibeam artifacts at 5-50 m; gray band indicates region of noise where AUV navigation artifacts are prevalent, and data resolution insufficient to properly characterize

883 individual features. b) Spectra from north-south sequence of boxes (numbered 3, 4 and 5 in inset map); Bars and abbreviations as in a). 


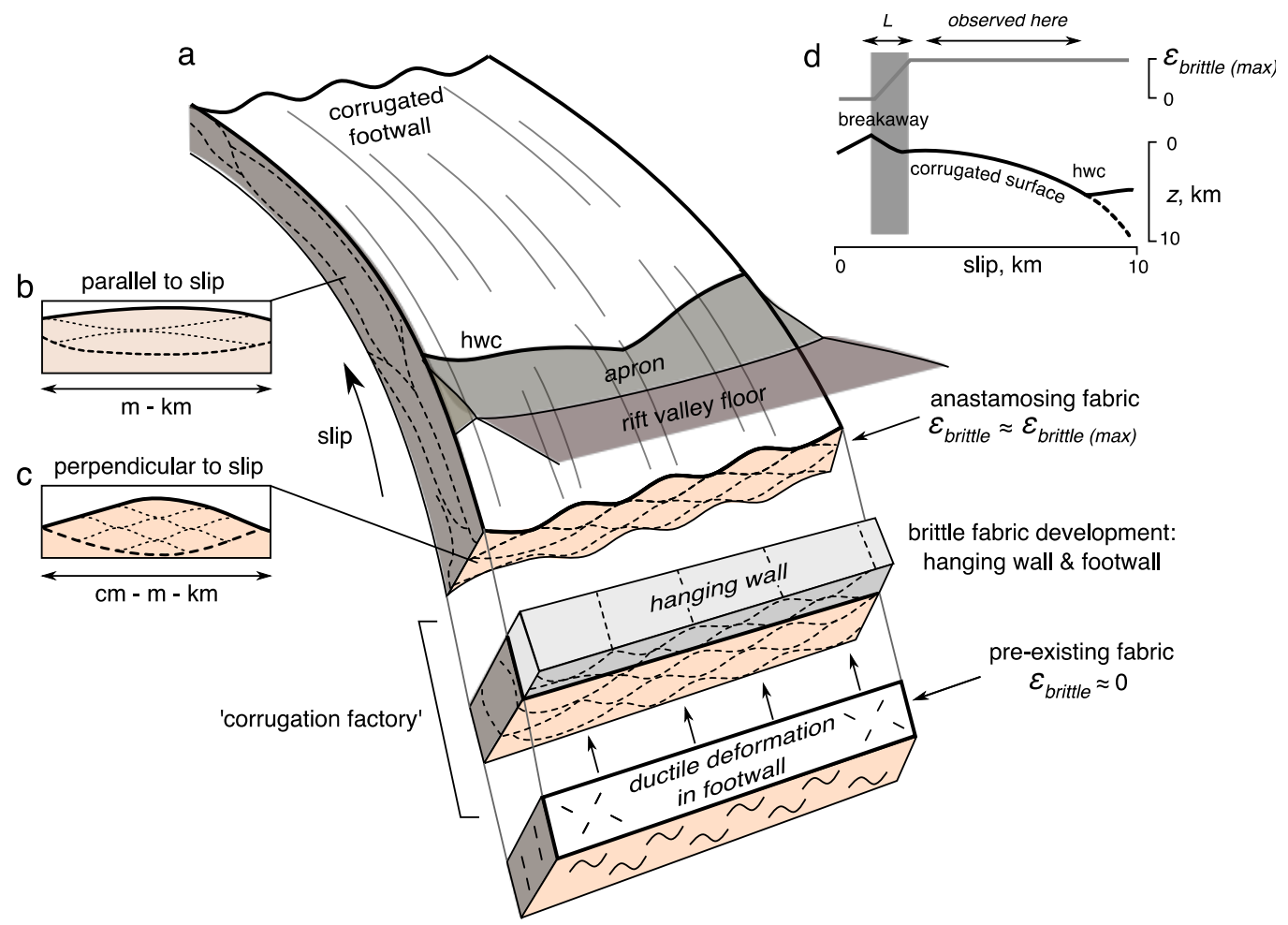

896 Figure 10. Sketch illustrating corrugation genesis via strain localization. a) Perspective 897 view through oceanic detachment fault, showing transition from footwall with pre898 existing ductile fabric (lower block), through corrugation factory (central block), and 899 exhumation (upper curved block). White area is upper footwall surface, gray lines are 900 corrugations; tan shading is footwall material, which acquires anastomosing fabric 901 (dashed lines) after passing through corrugation factory; gray block is hanging wall 902 material that also acquires anastomosing fabric; pink shading is rift valley floor (i.e., 903 hanging wall); yellow shading is apron extending up to hanging-wall cutoff (hwc). b) and 904 c) Insets showing anastomosing fabric oriented parallel and perpendicular to slip, 905 respectively. d) Lower thick line is schematic bathymetric profile (based upon $13^{\circ} 20^{\prime} \mathrm{N}$ 906 OCC), dashed line shows subsurface projection of fault surface. Upper solid line is brittle 907 strain, $\varepsilon$, as a function of total slip; $L$ is downdip extent of shear zone where strain is 908 accumulated; gray shading highlights region of increasing strain, probably resulting in 909 changing fault roughness beneath the breakaway/chaotic terrain (which are not observed 910 here); arrow shows extent of data coverage from this study, where brittle strain is 911 constant and relatively high, thus uniform fault roughness is expected. 
Figure 1 (high-resolution)

Click here to download Figure (high-resolution): figure1.pdf 
Figure 2 (high-resolution)

Click here to download Figure (high-resolution): figure2.pdf 
Figure 3 (high-resolution)

Click here to download Figure (high-resolution): figure3.pdf 
Figure 4 (high-resolution)

Click here to download Figure (high-resolution): figure4.pdf 
Figure 5 (high-resolution)

Click here to download Figure (high-resolution): figure5.pdf 
Figure 6 (high-resolution)

Click here to download Figure (high-resolution): figure6.pdf 
Figure 8 (high-resolution)

Click here to download Figure (high-resolution): figure8.pdf 
Figure 9 (high-resolution)

Click here to download Figure (high-resolution): figure9.pdf 
Figure 10 (high-resolution)

Click here to download Figure (high-resolution): figure10.pdf 
